\title{
Archaeological Testing in the Mission Concepción Courtyard (41BX12), San Antonio, Texas
}

Kristi H. Miller

Barbara A. Meissner

Follow this and additional works at: https://scholarworks.sfasu.edu/ita

Part of the American Material Culture Commons, Archaeological Anthropology Commons, Environmental Studies Commons, Other American Studies Commons, Other Arts and Humanities Commons, Other History of Art, Architecture, and Archaeology Commons, and the United States History Commons

Tell us how this article helped you.

This Article is brought to you for free and open access by the Center for Regional Heritage Research at SFA ScholarWorks. It has been accepted for inclusion in Index of Texas Archaeology: Open Access Gray Literature from the Lone Star State by an authorized editor of SFA ScholarWorks. For more information, please contact cdsscholarworks@sfasu.edu. 


\section{Archaeological Testing in the Mission Concepción Courtyard (41BX12), San}

Antonio, Texas

\section{Creative Commons License}

\section{(c) (1) (8)}

This work is licensed under a Creative Commons Attribution-NonCommercial 4.0 International License 


\section{Archaeological Testing in the Mission Concepción Courtyard (41BX12), San Antonio, Texas}

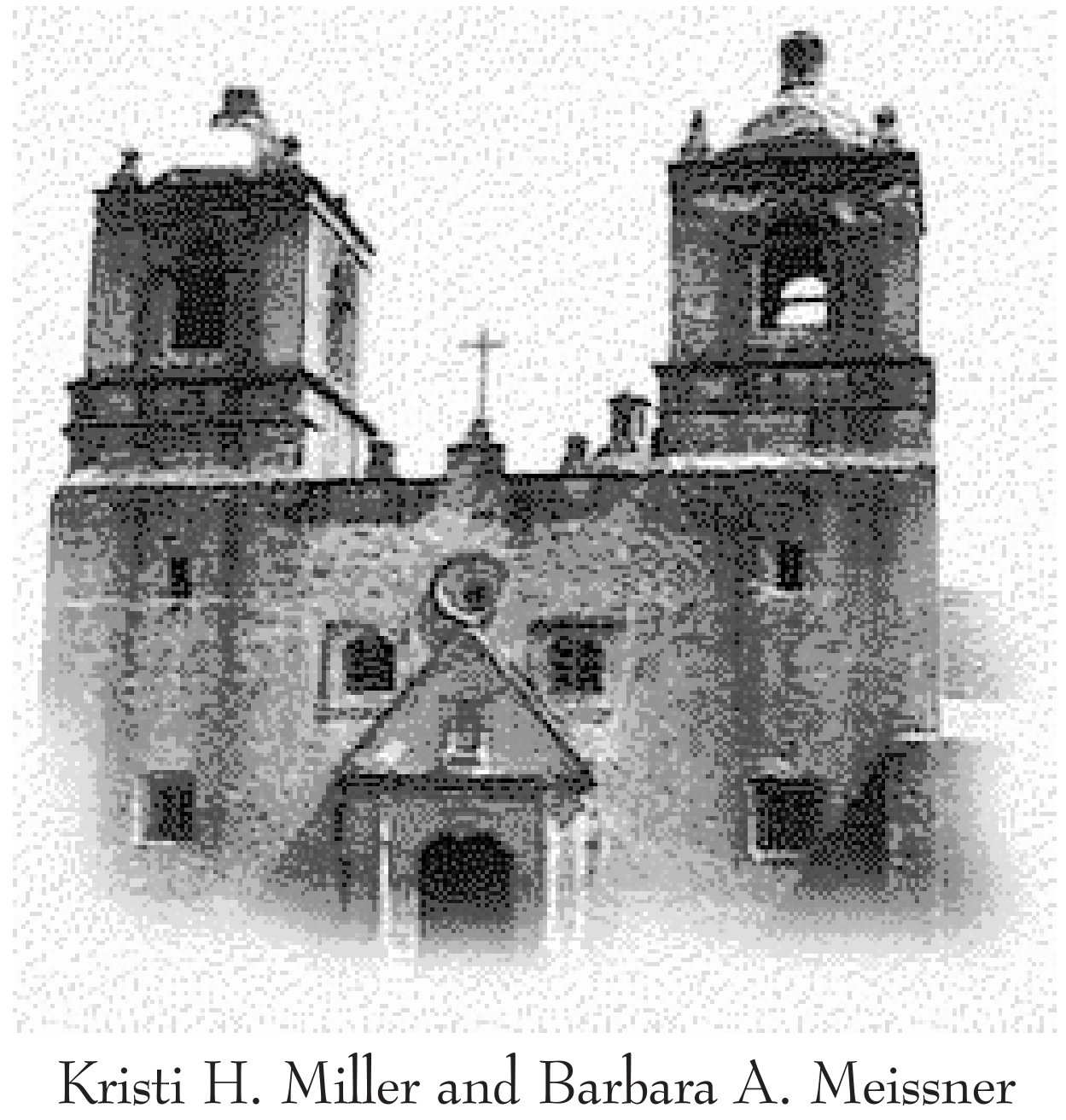

with a Contribution by
Steve A. Tomka

Center for Archaeological Research

The University of Texas at San Antonio Archaeological Survey Report, No. 304

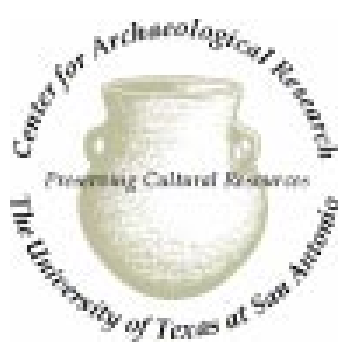




\title{
Archaeological Testing in the Mission Concepción Courtyard (41BX12), San Antonio, Texas
}

Kristi H. Miller and Barbara A. Meissner

\author{
with a Contribution by \\ Steve A. Tomka
}

Robert J. Hard

Principal Investigator

Texas Antiquities Permit No. 2313

${ }^{\circ}$ copyright 2001

Center for Archaeological Research

The University of Texas at San Antonio

Archaeological Survey Report, No. 304 
The following information is provided in accordance with the General Rules of Practice and Procedure, Chapter 41.11 (Investigative Reports), Texas Antiquities Committee:

1. Type of investigation: Testing

2. Project name: Concepción Courtyard Testing

3. County: Bexar

4. Principal investigator: Robert J. Hard

5. Name and location of sponsoring agency: National Park Service, San Antonio Missions National Historical Park, San Antonio, Texas

6. Texas Antiquities Permit No.: 2313

7. Published by the Center for Archaeological Research, The University of Texas at San Antonio, 6900 N. Loop 1604 W., San Antonio, Texas 78249-0658, 2001

A list of publications offered by the Center for Archaeological Research is available. Call (210) 458-4378; or write to the Center for Archaeological Research, The University of Texas at San Antonio, 6900 N. Loop 1604 W., San Antonio, Texas 78249-0658; e-mail address is car@lonestar.utsa.edu; or visit CAR's web site at http://car.utsa.edu. 


\begin{abstract}
This report describes archaeological investigations conducted in January, 2000 which constituted Phase 1 of a project designed to expose and stabilize the remaining walls and floors of Colonial period rooms south of the church at Mission Nuestra Señora de la Purísima Concepción de Acuña, in the southern part of San Antonio, Texas. This phase of the project, conducted by the Center for Archaeological Research, The University of Texas at San Antonio and sponsored by the National Park Service, was performed to determine the depth of the floors of the buried rooms within the courtyards, to allow architects to complete plans for the larger project. Archaeological investigations, consisting of four hand-excavated $1 \times 1 \mathrm{~m}$ units, established the depth at which the original floor appears at four points within the courtyard. Mission period pottery and evidence of later occupation were recovered during the excavations.
\end{abstract}




\section{Contents}

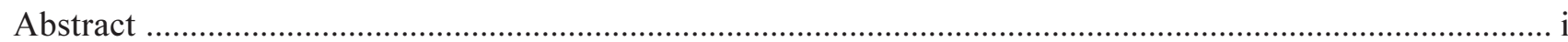

Figures

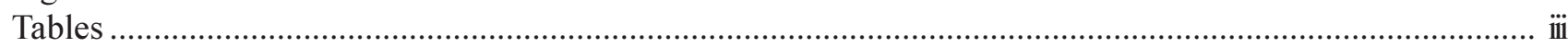

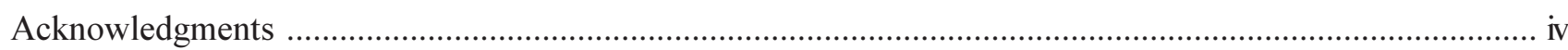

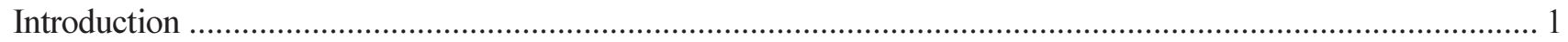

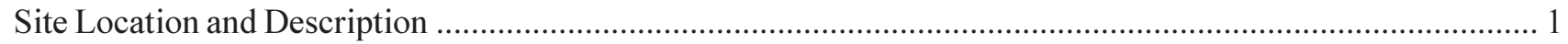

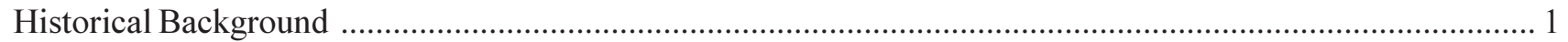

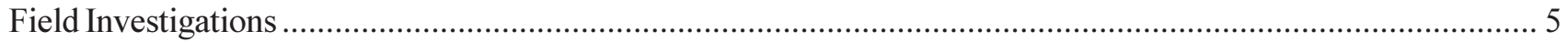

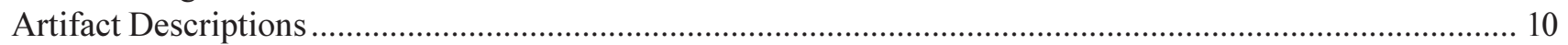

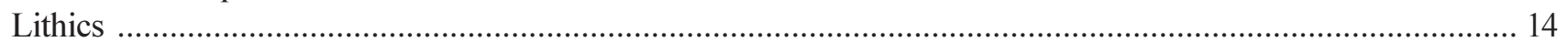

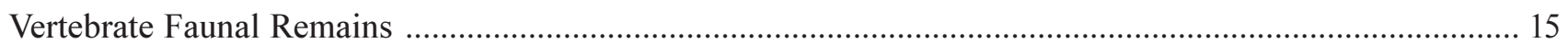

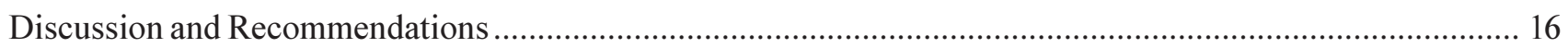

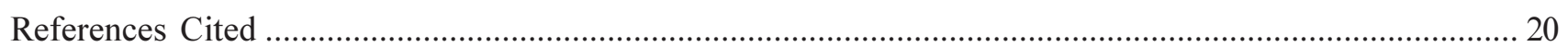

Appendix A

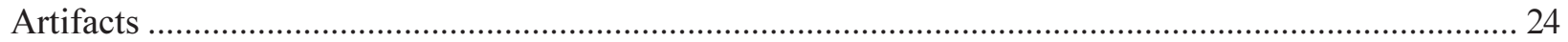

Appendix B

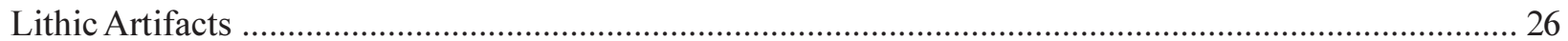

Appendix C

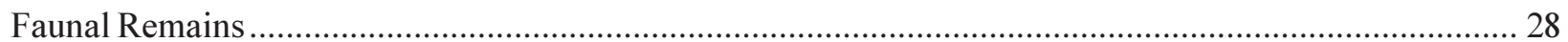




\section{Figures}

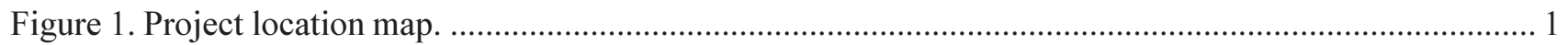

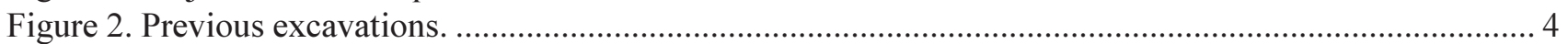

Figure 3. Project map, showing location of the 4 test units. ................................................................. 5

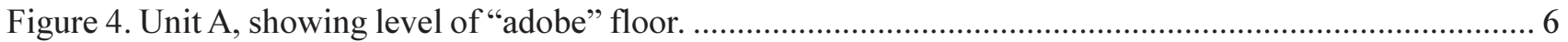

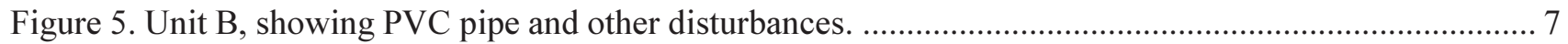

Figure 6. Unit C, showing brick and caliche walkway in profile of south wall and cast iron pipe.................... 7

Figure 7. Profile of south wall of Unit C, showing edge of brick walkway. ................................................. 8

Figure 8. Plan of Unit D, showing remains of rock wall in southern part of unit and floor remains. ................. 8

Figure 9. Unit D, showing rock concentration in southern $1 / 2$ of unit and remnant of floor. ............................ 9

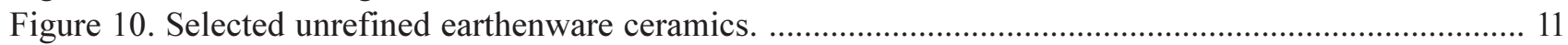

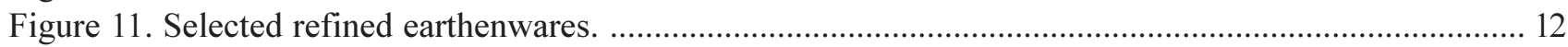

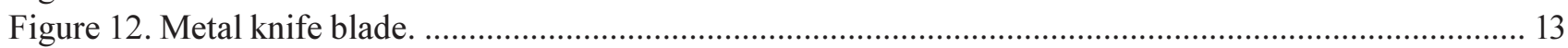

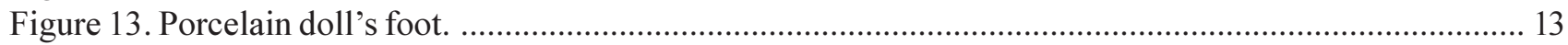

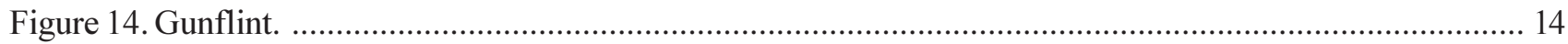

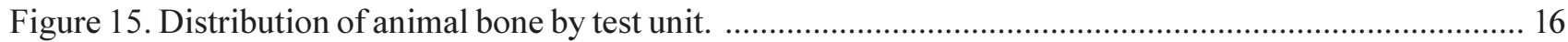

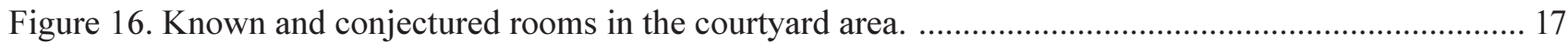

Figure 17. Comparison of refined versus unrefined wares in the 4 test units............................................. 18

\section{Tables}

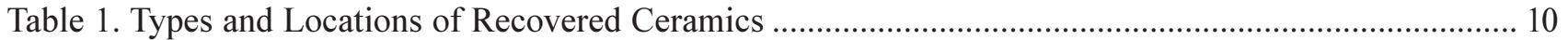

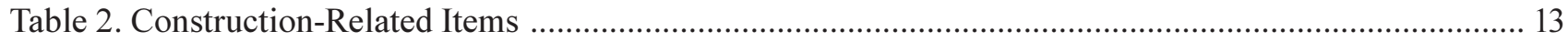

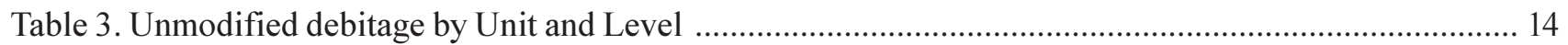

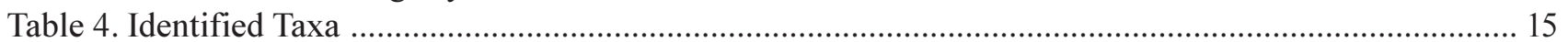




\section{Acknowledgments}

The authors would like to thank the staff at San Antonio Missions National Historical Park, for their cooperation during this project. We would especially like to thank Susan Snow, National Park Service staff archaeologist, and James Oliver, landscape architect in charge of planning the improvements in the courtyard area.

Principle Investigator for this project was Dr. Robert J. Hard, Director of the Center for Archaeological Research. Project Archaeologist was Barbara A. Meissner. Crew members included Kristi H. Miller, crew chief, and Richard Jones, Daniel Kruetzer, Brian Langner, and Carol Leezer.

Steve A. Tomka identified the lithics. Anne A. Fox helped with the ceramics. As always, the office staff, including Sherri Suñaz, our Administrative Assistant, were invaluable. We would also like to thank our technical editors, Maryanne King and Johanna Hunziker. 


\section{Introduction}

In January 2000, an archaeological crew from the Center for Archaeological Research (CAR), at the University of Texas at San Antonio (UTSA), under contract with the National Park Service (NPS), conducted excavations at Mission Nuestra Señora de la Purísima Concepción de Acuña (41BX12). The work conducted constituted Phase 1 of a project to expose and stabilize the remaining walls and floors of Colonial period rooms south of the church. This phase of the project, which was completed under permit number 2313 from the Texas Historical Commission (THC), was conducted to determine the depth of the original floors of the buried rooms within the courtyard (see Ivey and Fox 1999:10-16). This information was needed to allow architects to complete plans for the larger project. Archaeological investigations, consisting of four hand-excavated $1 \times 1 \mathrm{~m}$ units, established the depth at which the original floor appears at four points within the courtyard. The field work was completed in two working days.

\section{Site Location and Description}

Mission Concepción is located approximately 2.5 miles $(4 \mathrm{~km})$ south of downtown San Antonio (Figure 1). Mission Concepción is part of the San Antonio Missions National Historical Park and is a State Archaeological Landmark. It is also recorded by the Historic American Buildings Survey and is listed on the National Register of Historic Places. The mission church and remaining buildings of the mission are situated on a low rise near the San Antonio River.

\section{Historical Background}

The following is a very brief summary of the history of Mission Concepción. More detailed summaries can be found in Cox and Meissner 2000, Habig 1968, and Ivey and Fox 1999.

There is evidence that the Mission Concepción site was used by the Spanish prior to the establishment of the mission in 1731. Archival research indicates that

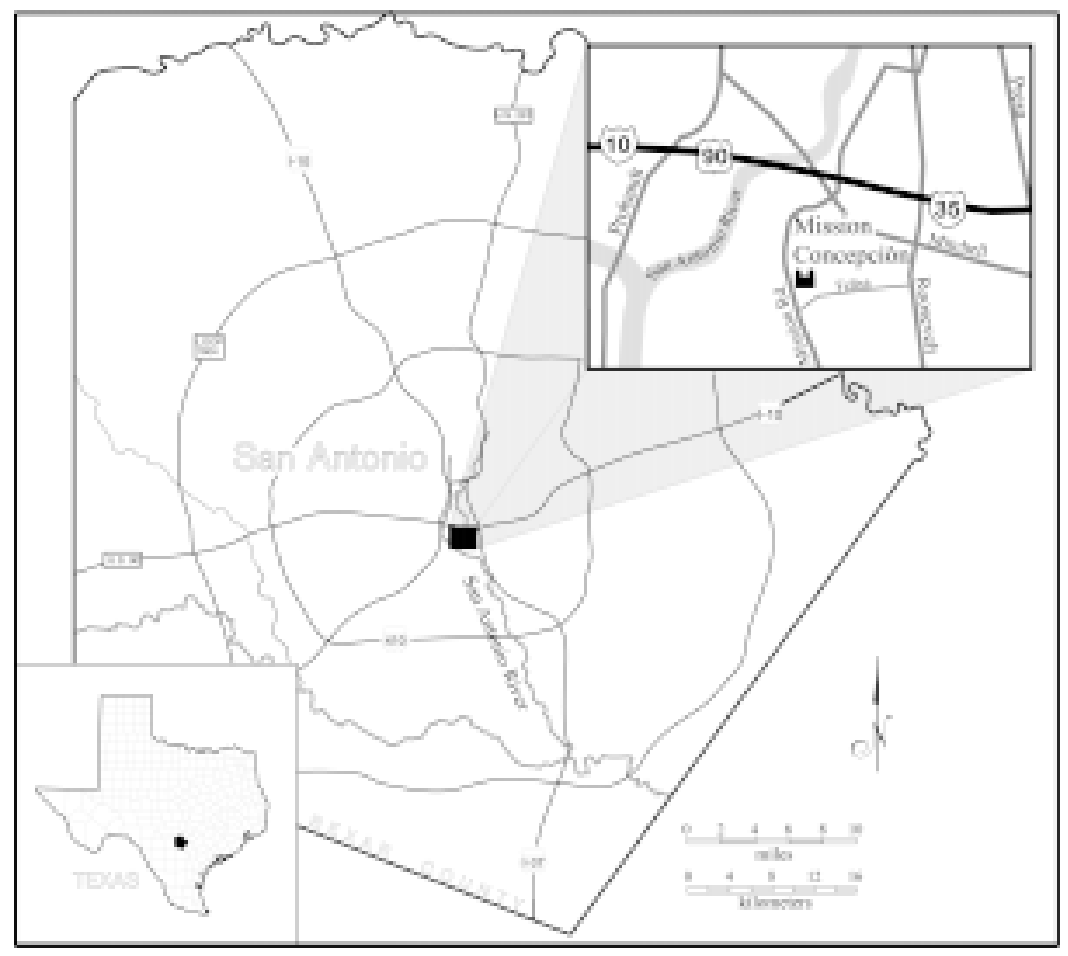

Figure 1. Project location map. 
this site may have been occupied by Mission San José y San Miguel de Aguayo at its initial founding and probably was the site of the short-lived Mission San Francisco Xavier de Nájera, which was abandoned about 1726 (Ivey and Fox 1999:45-46). Five years later the site was selected to be the new location of Mission Nuestra Señora de la Purísima Concepción de los Ainais, originally founded by Franciscan Missionaries in 1716, near the present-day Linwood Crossing in Nacogdoches County, Texas. When the mission was relocated to the San Antonio River in 1731 the name was altered to Nuestra Señora de la Purísima Concepción de Acuña. Concepción housed approximately 300 Native Americans at the time of the move (Habig 1968:125). Fray Ortiz reported that in 1745 the mission structures were built as stone wall fortresses that aided in protecting the inhabitants from Apache raids. Inside the walls were a church, a convento, a granary, and several other buildings, in addition to the jacales (mud-plastered wooden huts) which housed the Native Americans. At that time, a new stone church was under construction, and by the time of the next major report, in 1756, the church was completed (Habig 1968:126-129). This church still stands and is an active Catholic parish.

In 1772 the College of Zacatecas, which controlled Mission San José, was given authority over all missions in San Antonio. In 1794, at the time of partial secularization, there were only 38 Native Americans living at Concepción (Habig 1968:141). After 1819, mass was no longer being said at the church and by 1831 the lands around the mission that had not yet been sold, as well as all the remaining buildings except the church, were sold at auction (Habig 1968:147).

In 1860, Bishop John Mary Odin purchased the convento from Ramón Músquiz, giving it and the church to the Brothers of Mary. They restored the church and purchased some of the surrounding lands. In 1861, the church was re-consecrated (Habig 1968:149). Following the 1861 reopening of the church, the convento was utilized by the Brothers of Mary as a retreat center (Ivey and Fox 1999:48).

Most of the early structures seem to have been centered south of the extant mission buildings. Both archival and archaeological investigations indicate the presence of an adobe structure south of the current convento that probably acted as the church building from 1735-1740, and even possibly as late as 1755 (Ivey and Fox 1999:48). Other evidence indicates the presence of an adobe convento that existed before the 1745 construction of the extant stone convento (Ivey and Fox 1999:47). Construction of the present convento adjoining the church began ca. 1750 and was almost complete by 1756 (Ivey and Fox 1999:48).

The construction sequence of the workshop areas south of the church is less understood than that of the church and convento. Mention of a stone granary appears by 1745, and it is referred to in both the 1756 and 1772 inventories (Ivey and Fox 1999:47-48). It has been suggested that the construction of the granary must have started sometime around 1735, and was completed by 1745 (Ivey and Fox 1999:49). Ivey and Fox believe that, since the inventory of 1772 makes no mention of the other rooms south of the church, they were likely constructed after 1772 , but prior to 1838 when they were mentioned in land survey descriptions (Ivey and Fox 1999:48).

\section{Previous Investigations}

A number of archaeological investigations have taken place at Mission Concepción (Figure 2). They are briefly summarized here. In the $1930 \mathrm{~s}$, as part of a Works Progress Administration (WPA) project, archaeologists excavated around the standing mission walls, and documented foundations for many buildings that had long-since disappeared (Ivey and Fox 1999:4).

During the fall of 1971 and the spring of 1972, parts of the west wall were uncovered across the road from the mission (Scurlock and Fox 1977). Excavations during 1981 and 1982 uncovered remains of several structures, including parts of the northeast corner, a portion of the west wall, and parts of the north wall (Ivey and Fox 1999). One of the main foci of the 19811982 project was the excavation of the granary structure. Investigations revealed that four blocks of excavation, consisting of four units each, adequately defined the area of the granary. Four rooms were tentatively identified within this area. Ivey and Fox (1999) designated the rooms as follows: 
Room 1, was identified as the interior of the Yturri house (a residence of previous landowner Manuel Yturri y Castillo). This room had no clear floor surface, possibly because it was located near or at the surface and was disturbed by the clearing of rubble.

Room 2, located south of the south portion of the Yturri house, exhibited a hard, white plaster floor at approximately 15.5 inches $(39 \mathrm{~cm})$ below the surface.

Room 3, exhibited a series of packed earth and adobe floors appearing at seven inches $(18 \mathrm{~cm})$ below the surface. The room had apparently fallen by the early 1830 s as there is no reference to such a room in the 1838 description or the 1849 survey.

Room 4, was identified as the interior of the granary. It appeared highly disturbed, but revealed that at one time there had been a hard, white plaster or adobe floor.

Beneath these rooms was evidence of two prior phases of construction. Stone foundations were reused in part of a room located south of the granary, and evidence of a plaster floor south of Room 1 suggested that an earlier construction extended further south (Room 2). Adobe foundations were found beneath stone foundations that may date to the period immediately after the mission's arrival in San Antonio in 1731. Little information is known concerning this construction period (Ivey and Fox 1999:10-16).

In 1986, CAR archaeologists tested an area south of the church. These excavations showed that:

(1) Smith's 1930s WPA maps were based in part on assumptions about the nature of the buried walls, and were not completely accurate; and

(2) Although the remains of several walls were present, the artifacts recovered indicated that considerable disturbance had taken place in the area (Fox 1988:20).
In February of 1987, archaeologists were sent to the mission to assess the possible damage to any Spanish Colonial resources by the proposed realignment of Mission Road (Labadie 1989). Labadie focused on the location of three possible acequias and other possible undisturbed mission remains that would be affected by the realignment. Testing revealed that the area had previously been disturbed. Labadie (1989) concluded no undisturbed evidence of prehistoric and early historic occupation was revealed during this phase of the Mission Road Realignment Project.

CAR personnel also monitored the construction of an electrical conduit trench and a condensation line for an air conditioning system. The electrical conduit trench, which ran south from the church, crossed one wall, presumably part of the foundation of the first convento (Fox 1989).

In 1990, test excavations were conducted by CAR to determine the extent of cultural resources remaining within the mission courtyard. Wall foundations of the eastern portion of the convent were located. Remnants of a storeroom were located between the granary and the convent. An adobe-like surface was revealed at a depth of approximately $39 \mathrm{~cm}$ that represents the storeroom flooring. Other excavation units revealed granary wall foundations and remains of the wall buttress (Krueger and Meskill 1992:16). Another project, undertaken in 1990, assessed the potential damages of utility and house construction, while locating the northwest corner of the mission complex (Brown et al. 1994).

In March of 1999, after workmen excavating a manhole south of the mission found large numbers of animal bone, a previously unknown section of acequia was uncovered (Meissner 2000). Archaeologists determined that this portion of the acequia had been filled in the Colonial period, mostly with building debris, and was later used as a trash dump. While monitoring the digging of electrical conduit trenches just north of Felisa Street in April of 1999 (see Figure 1), archaeologists recorded a stone wall running east-west, and a trench that many have been the footing for a palisade wall running north-south (Robinson 2000). 


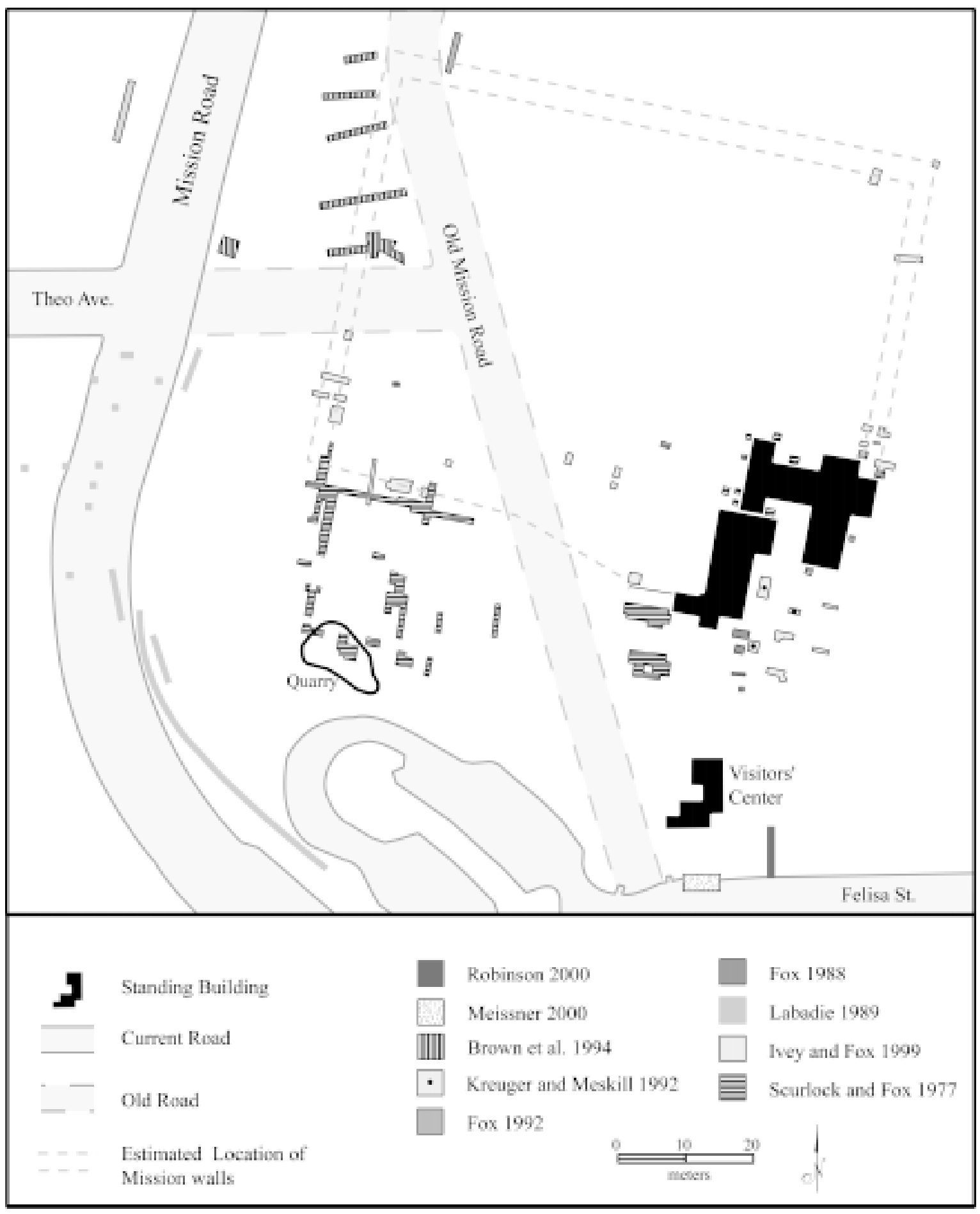

Figure 2. Previous excavations. 


\section{Field Investigations}

The CAR field investigations for this project were located in the courtyard area south of the current church (Figure 3). Measurements were taken according to the metric system. Four $1 \times 1 \mathrm{~m}$ units were excavated by hand using shovels, trowels, and brushes. All matrix was sifted through $1 / 4$ inch $(.64 \mathrm{~cm})$ screen. All collections were processed, cataloged, and curated at the CAR laboratory.

\section{Unit A}

Unit A was excavated in two levels. Level $1(0-10$ $\mathrm{cm}$ ) contained very little cultural material. Some brick fragments, mortar fragments, chert flakes, and plastic were recovered from this level. Level $2(10-19 \mathrm{~cm})$ yielded a mixture of modern and nineteenth century goods. Items recovered from this level include bone, ceramic fragments, glass fragments, a 1945 U.S. penny, a knife blade, brick and mortar fragments, and metal scrap. At approximately $19 \mathrm{~cm}$ below the surface, a floor was encountered in the northwest corner of the unit. This floor appeared to have been made by packing a mixture of clay, sand, and caliche, and allowing it to set into a fairly hard surface. Ivey and Fox (1999:15) refer to this type of floor as "hard-packed, tan adobe." In the rest of the unit the floor was found at $20 \mathrm{~cm}$ below the surface. It appeared to have been somewhat disturbed in the middle section of the unit, and was hardest and least disturbed along the east side of the unit (Figure 4).

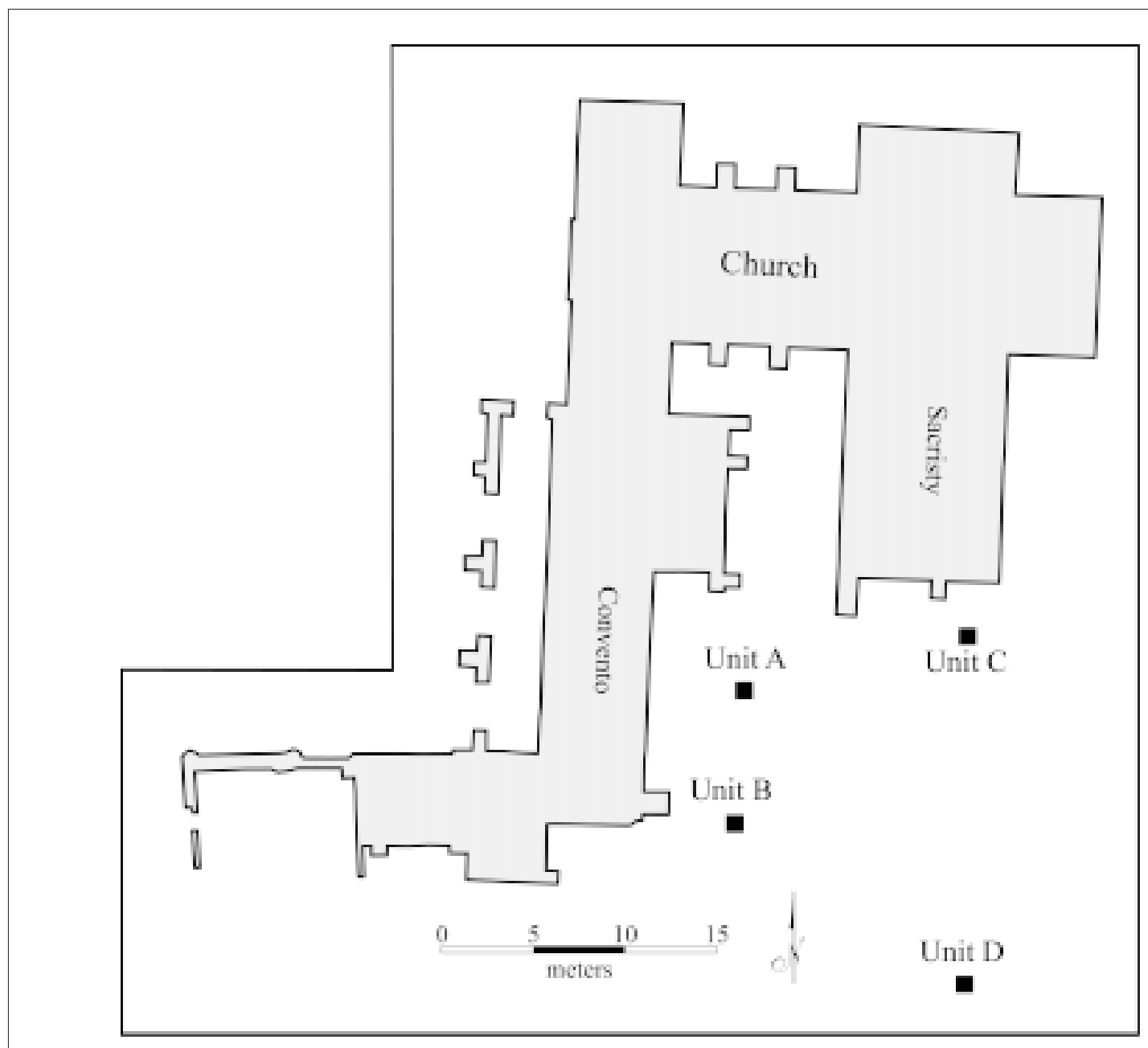

Figure 3. Project map, showing location of the four test units. 


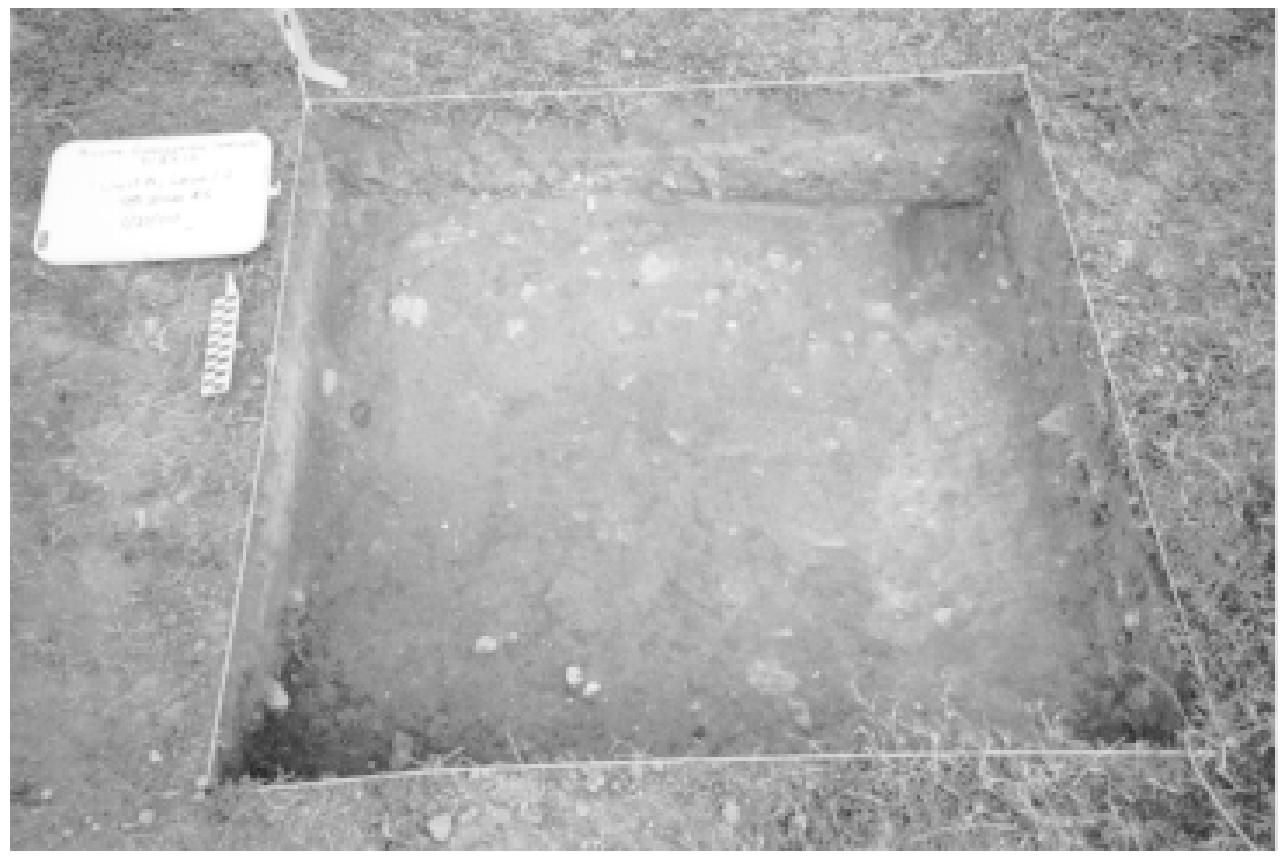

Figure 4. Unit A, showing level of "adobe" floor.

\section{Unit B}

Unit B was excavated in two levels. Level 1 (0-10 $\mathrm{cm}$ ) yielded little cultural material. The level contained brick and mortar fragments, bone, chert flakes, ceramics, pull tabs, a porcelain doll foot, plastic fragments, and tar. Level 2 (10-20) contained an increased number of ceramic fragments, along with glass fragments, brick and mortar fragments, bone, chert flakes, and a forged nail. A floor was revealed at approximately $12 \mathrm{~cm}$ below the surface in the southwest region of the unit, $15 \mathrm{~cm}$ below the surface in the northeast corner and at $17 \mathrm{~cm}$ below the surface in the northwest corner. A PVC pipe runs from the southwest corner of the unit at an angle to the west wall of the unit, and there is evidence of other disturbances affecting the floor. This floor had more caliche mixed into the clay, and was harder, whiter, and more easily defined even though it was in a more disturbed state than the floor in Unit A (Figure 5).

\section{Unit C}

Unit C was excavated in three levels. Level $1(0-10$ $\mathrm{cm}$ ) had an artifact inventory of glass fragments, bone, ceramics, chert flakes, and wire nails. The southeast corner appeared to contain a caliche floor at $10 \mathrm{~cm}$ below the surface. Further excavations showed that the caliche was limited to the southern edge of the unit. Level $2(10-20 \mathrm{~cm})$ yielded chert flakes, ceramics, bone, glass fragments, a .22 caliber casing, and 2 bricks labeled "Corsican Brick." The hard caliche surface along the southern edge of the unit covered the northern edge of a brick walkway.

Level $3(20-30 \mathrm{~cm})$ contained glass fragments, chert flakes, bone, and ceramics. A cast iron pipe and associated trench was uncovered (Figure 6). It appeared that the packed caliche and bricks were part of a walkway along the southern edge of the unit (Figure 7). This walkway had been constructed in three episodes: 1) a layer of hard-packed caliche; 2 ) a layer of bricks set onto a layer of limestone gravel; and 3) another layer of packed caliche, laid down after the bricks had become covered with sediment (Figure 7). The "adobe" floor was uncovered intact in the southeast corner at $31 \mathrm{~cm}$ below the surface, directly beneath the packed caliche walkway. A somewhat larger area of intact floor was also uncovered in the southwest corner. In the northwest corner and throughout the center of the unit the flooring was disturbed, appearing in places at about $29-30 \mathrm{~cm}$ below the surface. 


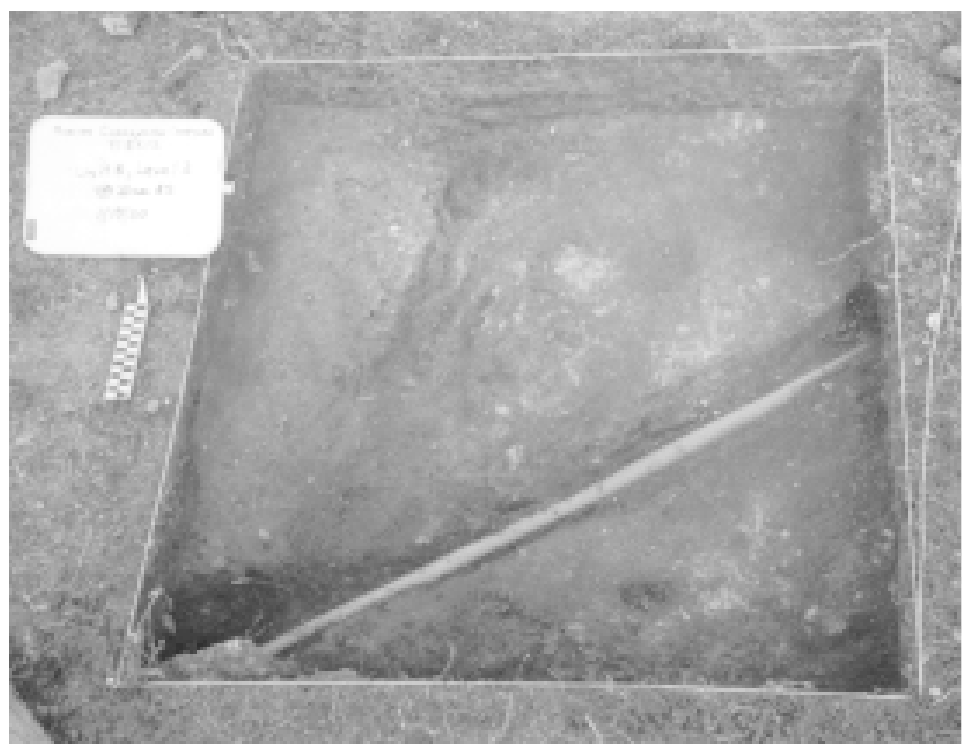

Figure 5. Unit B, showing PVC pipe and other disturbances.

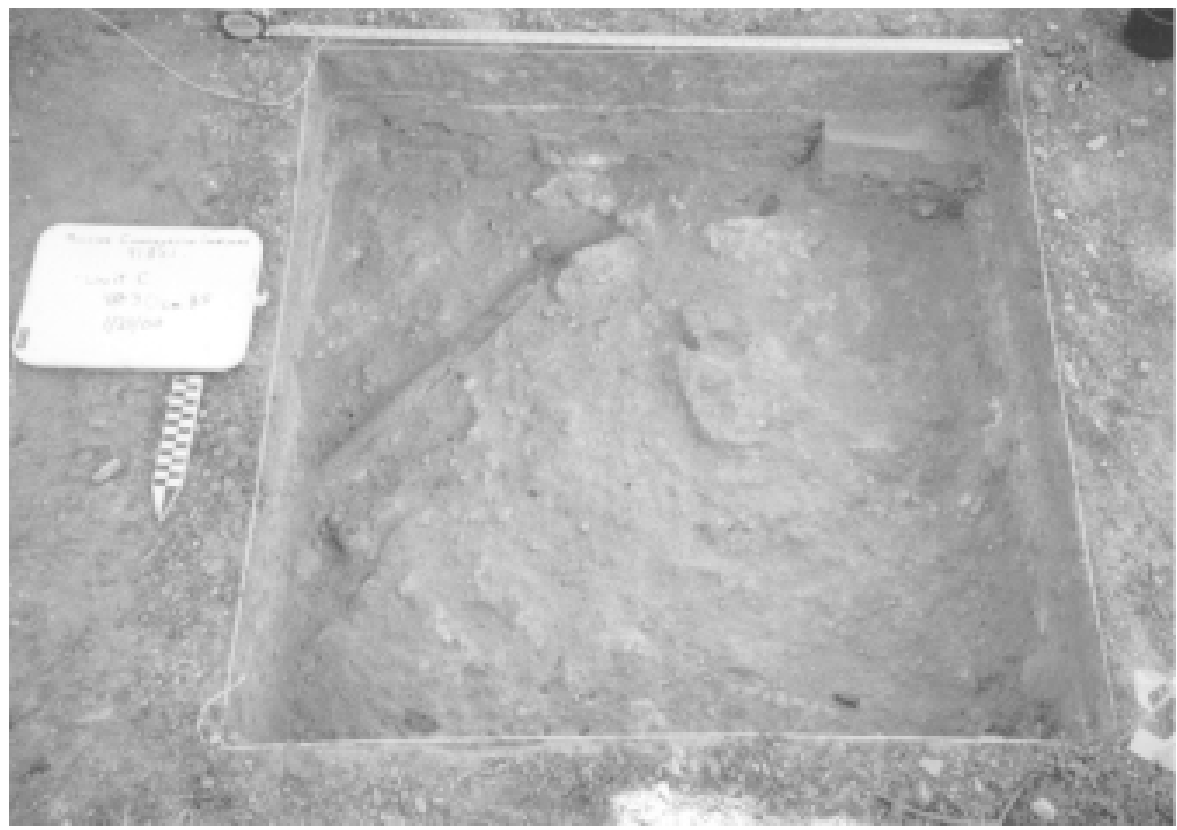

Figure 6. Unit C, showing brick and caliche walkway in profile of south wall and cast iron pipe. Remnants of "adobe" floor are most visible in the northwestern quadrant of the unit. Looking south. 


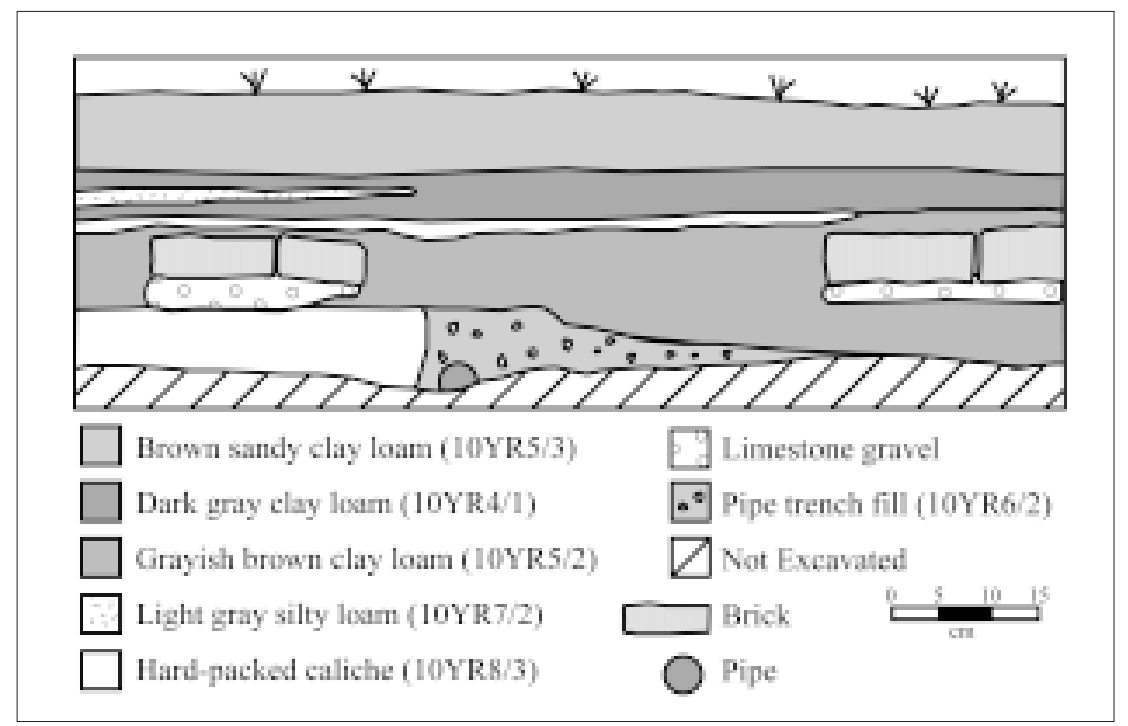

Figure 7. Profile of south wall of Unit C, showing edge of brick walkway.

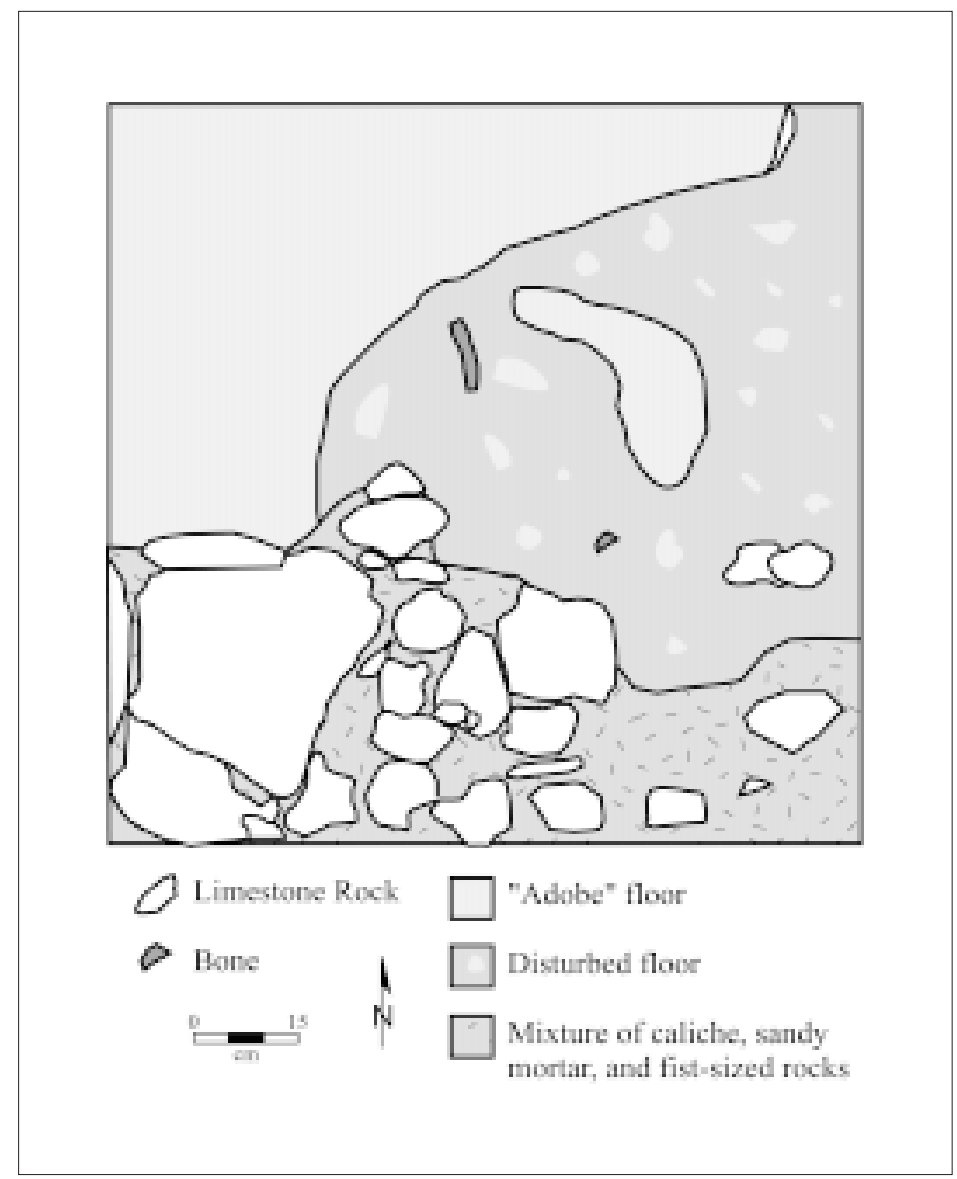

Figure 8. Plan of Unit D, showing remains of rock wall in southern part of unit and remains of floor in northwest corner. 


\section{Unit D}

Unit D was excavated in three levels. Level $1(0-10$ $\mathrm{cm}$ ) contained glass fragments, bone, tar, nails, and one half of a shell button. Level $2(10-20 \mathrm{~cm})$ yielded an increased number of bone fragments and ceramics. It also contained glass fragments, brick and mortar fragments, and tar. At approximately $15 \mathrm{~cm}$ below the surface a concentration of rocks appeared in the southwest corner stretching to the southeast corner Figure 8). This probably represents the south wall of the room described as Room 1 on the reconstruction of the mission illustrated in Figure 4 in Ivey and Fox (1999:9). Unit D is located east of Block 1 shown in Figure 5 of that same publication (Ivey and Fox 1999:11). In Level $3(20-30 \mathrm{~cm})$ the artifact inventory contained ceramics, bone, metal fragments, and mortar fragments. A floor was encountered at $25 \mathrm{~cm}$ below the surface in the northwest quadrant of the unit (Figure 9). Fragments of the floor appeared throughout the northeast portion, though it was highly disturbed.

\section{Discussion}

The remains of floors were located in each of the four test units excavated during this project, but were found to be disturbed in each of the units. These floors are fairly easy to define when encountered, although if they are disturbed definition becomes more difficult. The floor in Unit B seemed to have a great deal more caliche in it, and was much easier to determine.

The results of this limited testing project, combined with information from Ivey and Fox (1999:10-15) and Krueger and Meskill (1992:7-10), demonstrates that remnants of floors of the buried rooms can be expected to be present over much of the courtyard, though they are probably in a disturbed or destroyed state in many areas.

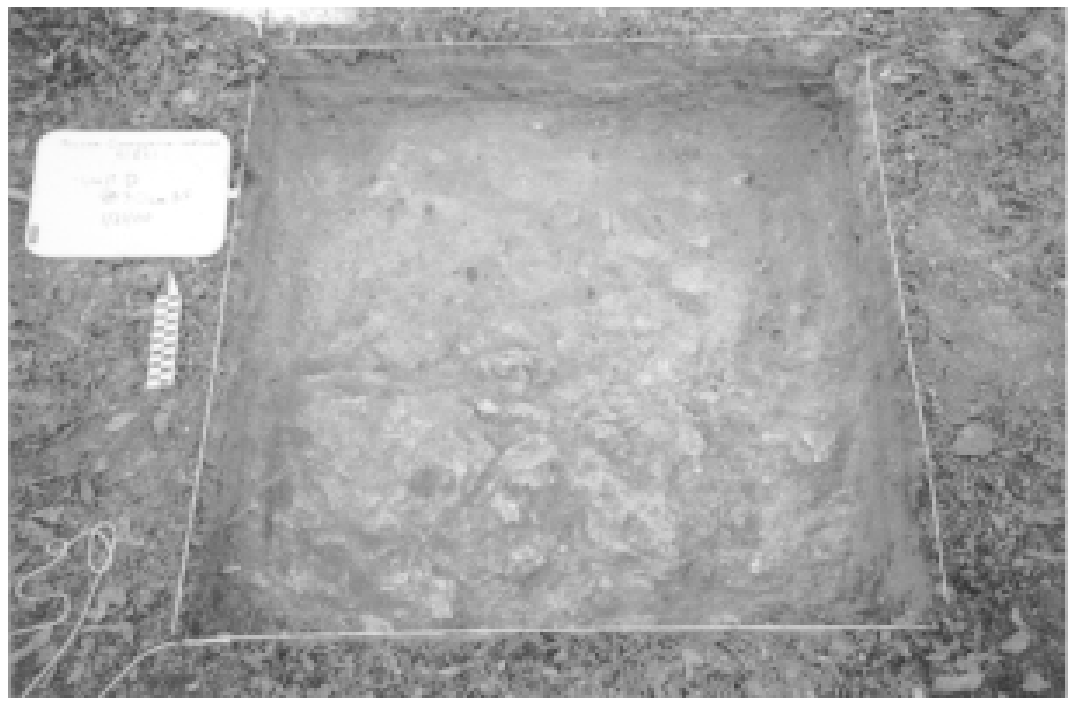

Figure 9. Unit D, showing rock concentration in southern half of unit and a remnant of floor in the northwest corner. Looking north. 


\section{Artifact Descriptions}

In this section, brief descriptions of the artifacts recovered during the project are given. A complete, provenienced artifact list is in Appendix A.

\section{Household Items}

\section{Ceramics}

A total of 68 sherds of ceramics were recovered during the project. Table 1 shows the ceramic types and locations.

\section{Unrefined Wares}

\section{Unglazed wares}

Unglazed wares manufactured at the missions comprise the largest percentages of ceramics recovered from all San Antonio mission sites (Brown et al. 1994:15). During this project, Valero ware, a predominantly eighteenth century ceramic type, was the most common of the unglazed wares. Valero ware is a wheel-made ceramic with a smooth, pinkish paste. The vessels were most likely fired in kilns due to the uniform color from the core to the surface. Valero wares were popular at the San Antonio missions from ca. 1730 to 1760 (Ivey and Fox 1999:37; Dial 1992:31). Twenty fragments of Valero ware were recovered (Figure 10a). In addition, 5 sherds of Goliad ware were recovered (Figure 10b). Goliad ware is a bone-tempered, hand-built ceramic type that is often associated with the mission Natives of Spanish Colonial times (Dial 1992:29). It is believed that Goliad ware is a direct continuation of the local Leon Plain prehistoric ceramic tradition (Ivey and Fox 1999:37).

Burnished wares present at Mission Concepción reflect pre-Columbian Mexican traditions that still persist to this day. Red Burnished wares exhibit a glossy surface on a fine-grained paste. This type may have been brought in from Mexico either by traveling Natives or by supply trains (Dial 1992:32). There are five pieces of Red Burnished ware in this collection (Figure 10c).

\section{Glazed wares}

Lead-glazed wares often comprise a large portion of the ceramic assemblages of Spanish Colonial sites. These include: sandy paste utility wares, Olive jars, fine textured paste, and miscellaneous lead-glazed wares (Dial 1992:33-34). Five lead-glazed ceramic sherds were recovered, one of which is a rim sherd molded in a complex design (Figure 10d)

Table 1. Types and Locations of Recovered Ceramics

\begin{tabular}{|c|c|c|c|c|c|c|c|c|c|c|c|}
\hline & Unit & $\mathrm{A}$ & \multicolumn{2}{|c|}{$B$} & \multicolumn{2}{|c|}{$\mathrm{C}$} & \multicolumn{3}{|c|}{$\bar{D}$} & \multirow[b]{2}{*}{ Totals } \\
\hline & & Lv. & \begin{tabular}{l|l}
1 & 2 \\
\end{tabular} & 1 & \begin{tabular}{l|l}
1 & 2
\end{tabular} & 12 & $\begin{array}{ll}2 & 3 \\
\end{array}$ & 1 & 2 & 3 & \\
\hline Unrefined & Unglazed & Goliad & & & & 1 & 3 & & & 1 & 5 \\
\hline & & Valero & & & & & 1 & & 6 & 13 & 20 \\
\hline & & Burnished & & & & & & & 3 & 2 & 5 \\
\hline & Lead-glaze & & 2 & 2 & & & 1 & & 1 & 1 & 5 \\
\hline & Tin-glazed & Huejotzingo & & & & & & & 3 & 2 & 5 \\
\hline & & Puebla B-on-W & 2 & & 1 & & & & 1 & 1 & 5 \\
\hline & & Undecorated & 1 & & & 2 & & & 1 & 3 & 7 \\
\hline & Total Unre & fined & \begin{tabular}{l|l}
0 & 5 \\
\end{tabular} & 50 & 1 & \begin{tabular}{l|l}
3 & 0 \\
\end{tabular} & \begin{tabular}{l|l}
0 & 5 \\
\end{tabular} & 0 & 15 & 23 & 52 \\
\hline Refined & Whiteware & Hand painted & & & 1 & & 1 & & & & 2 \\
\hline & & Transfer & & & 1 & & & & & & 1 \\
\hline & & Banded slip & 1 & & & 2 & 2 & & & & 3 \\
\hline & & Undecorated & & & 2 & 12 & 2 & & & & 5 \\
\hline & Porcelain & & & & 1 & & & & 1 & & 2 \\
\hline & Stoneware & & 1 & & 1 & -1 & 1 & & & & 3 \\
\hline & Total Ref & ned & 02 & 20 & 6 & 15 & $\begin{array}{ll}5 & 1 \\
\end{array}$ & 0 & 1 & 0 & 16 \\
\hline & & Total Ceramic & \begin{tabular}{l|l}
0 & 7 \\
\end{tabular} & 70 & 7 & 45 & $\begin{array}{ll}5 & 6 \\
\end{array}$ & 0 & 16 & 23 & 68 \\
\hline
\end{tabular}


Figure 10. Selected unrefined earthenware ceramics: a) example of Valero ware, from Unit D, Level 2; b) example of Goliad ware, from Unit C, Level 3; c) example of Burnished ware, from Unit D, Level 2; d) molded lead-glazed rim sherd from Unit D, Level 3; e-g) Huejotzingo majolicas from Unit D (e-f are from Level 2 and $\mathbf{g}$ is from Level 3) ; h) Puebla Blue on White majolica from Unit D, Level 2; i) Puebla Blue on White majolica from Unit D, Level 3; j) two mended pieces of undecorated majolica, from Unit $\mathrm{D}$, Level 3, showing poorly applied glaze; k) undecorated majolica fragment of foot ring from Unit A, Level 2.

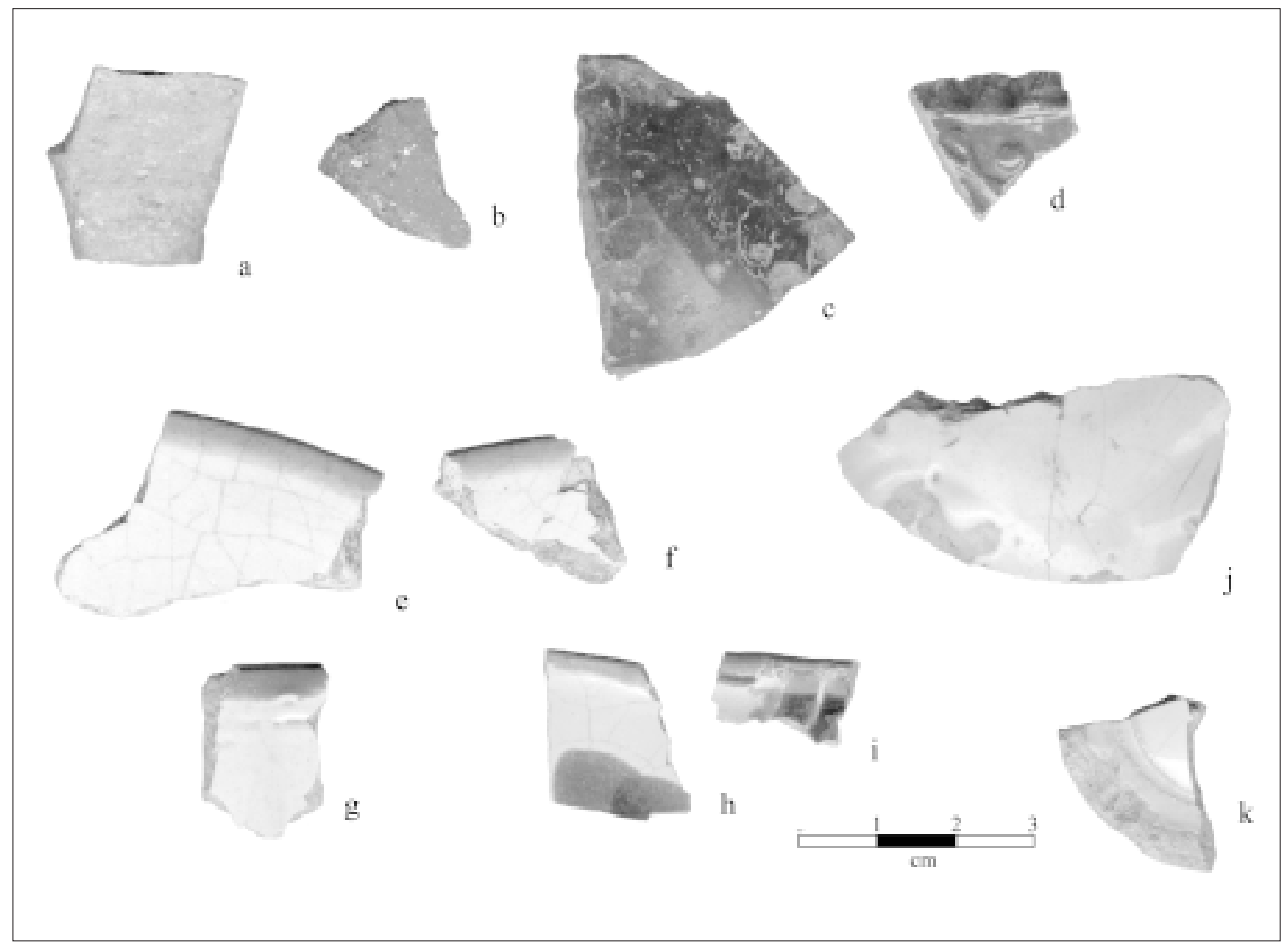

Mexican manufactured tin-glazed earthenware, also referred to as majolica, constitutes a small portion of ceramics recovered from South Texas mission sites (Brown et al. 1994:15), although not found in great quantities, the majolicas can sometimes offer important information to determine the dates of occupation (Ivey and Fox 1999:38). Unfortunately, the identifiable majolicas recovered during this project were two varieties known to have been manufactured over long periods of time. Five fragments of Huejotzingo majolica were recovered during the course of this project (Figure 10eg). These fragments contain the single blue rim band characteristic of this majolica type, which can be approximately dated to a time between the eighteenth and early-nineteenth centuries (Ivey and Fox 1999:40). Five fragments of Puebla Blue on White, which also can be dated to a time in the eighteenth century (Hard et al. 1995:47), were recovered (Figure 10h-i).

Seven pieces of unidentifiable majolica were present in the artifact inventory. These fragments contain no design and are white in color. Two of these, which mend together, form part of a bowl (Figure 10j), and are glazed with thick tin which was poorly applied. Another undecorated sherd is part of a foot ring (Figure 10k). 


\section{Refined Earthenwares}

\section{Whitewares}

Whitewares were first manufactured in England and Europe, and were being made in the United States by the middle of the nineteenth century (Brown et al. 1994:16). Whitewares characteristically exhibit a hard cream to gray white paste that results from highly fired refined clays. Vitreous glazes -occasionally with a bluish tint- are commonly used on whiteware vessels (Tennis 1997:2; Dial 1992:38). These wares can be dated to the nineteenth and twentieth centuries, and are generally considered post-Colonial in San Antonio (Brown et al 1994:16). Eleven fragments of whiteware were recovered during this project. Of these, two were handpainted (Figure 11a-b), one was transfer decorated (Figure 11c), and three were banded slip decorated (see Figure 11d for example). Handpainted whitewares were popular in Texas during the 1800s (Dial 1992:41). Transfer decorated wares were first produced in England during the 1750s and were popular in the United States well into the 1850s. A resurgence of popularity occurred in the last quarter of the nineteenth century (Tennis 1997:6). Banded slip decorated wares with a simple blue banded theme were popular in Texas after 1840. Before 1840, the mocha variety (such as the sherd illustrated in Figure 10d) was popular in the state (Tennis 1997:6).

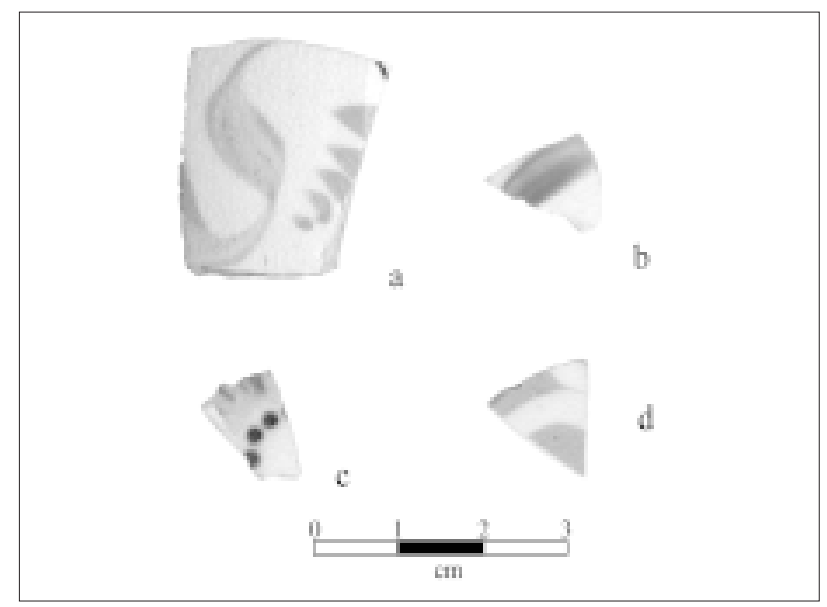

Figure 11. Selected refined earthenwares: a) handpainted whiteware from Unit C, Level 3; b) handpainted whiteware from Unit B, Level 2; c) transfer decorated whiteware from Unit B, Level 2; d) banded slip decorated whiteware from Unit C, Level 2.

\section{Porcelain}

Two fragments of European porcelain were present in the artifact inventory. Although Chinese porcelain is occasionally found in Colonial contexts, these sherds are probably post-Colonial (A. Fox, CAR, personal communication 2000).

\section{Stoneware}

Stoneware vessels are very hard, dense ceramics that possess moderately coarse clay. These clays are typically fired at temperatures between $1200^{\circ}$ and $1400^{\circ}$ C (Tennis 1997:16) causing the clay to vitrify and become impermeable (Dial 1992:45). Most stoneware recovered from the mission sites was produced relatively late, sometime after 1860 (Dial 1992:45). Nine stoneware potteries were operating in San Antonio from the late-1800s to the mid-1900s (Tennis 1997:16). Three small sherds of stoneware were recovered during this project.

\section{Other Household Items}

\section{Glass}

Glass container fragments recovered at the site $(n=47)$ can be dated to a time between the eighteenth century and the late-twentieth century. The fragments found were small in size and number, leaving it difficult to determine types. In addition, two fragments of glass from a kerosene lamp chimney were recovered.

\section{Tableware}

A knife blade was recovered from Unit A, Level 2 (Figure 12). It is similar in form to a small kitchen knife (cuchillos carinzeros) used in food preparation and consumption (Simmons and Turley 1980:130). This is the typical form of a Spanish Colonial knife, a straight cutting edge with the back of the blade sweeping to meet the tip in a convex arc, forming what is called the beak point (Simmons and Turley 1980:130).

\section{Personal Items}

One fragment of a button made from a freshwater mussel shell was recovered from Unit D at the bottom 
Figure 12. Metal knife blade.

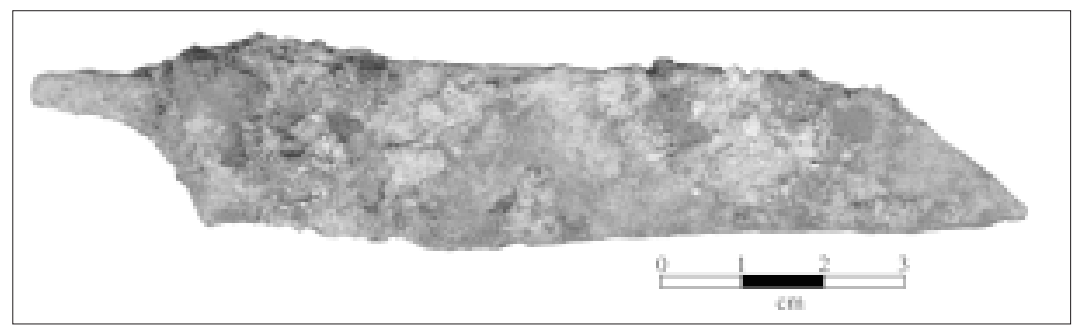

of Level $1(0-10 \mathrm{~cm})$. The button is approximately 1.3 $\mathrm{cm}$ in diameter with a concave, iridescent face. Machine cut shell buttons replaced hand cut buttons starting about 1850 (Meissner 1997a:119-127). This button appears to have been handmade. The diameter is not uniform and the two holes are slightly askew indicating that the button was not of machine manufacture. It is a very thin, poor quality button. The back of the button is the outer shell of the mussel, somewhat smoothed by polishing.

One penny was located in Unit A, Level 2. The penny was struck in 1945 at the Denver Mint. Pennies struck during this year were made of "shell case" copper. Shell cases had been salvaged ca. 1944 due to the scarcity of copper (Yeoman 1967:89).

\section{Activities}

One porcelain doll foot was found in Unit B Level 1 (Figure 13). The fragment is approximately $1.9 \mathrm{~cm}$ in length with the shoe painted blue while the stocking portion is white. This foot would have been sewed to a cloth-bodied doll, along with porcelain arms and head. It belonged to a doll which was probably manufactured between about 1860 and 1910 (Meissner 1997b:59-76).
Arms

One copper .22 caliber casing was recovered from Unit C, Level 2. The casing exhibited a small indentation on the edge of the base indicating that it had been fired. The bottom marking is an " $\mathrm{H}$ " and it is possible that it was manufactured by WRA (Winchester Repeating Arms Co., post 1921) (Logan 1959:160).

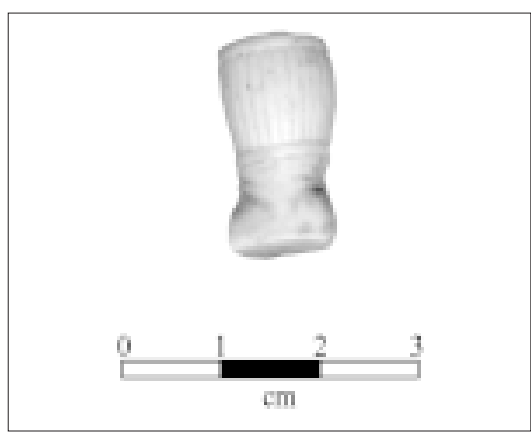

Figure 13. Porcelain doll's foot.

\section{Construction}

Table 2 gives a brief description of the artifacts relating to construction that were recovered during the course of the project.

Table 2. Construction-Related Items

\begin{tabular}{|c|c|c|c|c|c|c|c|c|c|c|}
\hline Unit & Level & $\begin{array}{c}\text { Window } \\
\text { Glass }\end{array}$ & $\begin{array}{c}\text { Wire } \\
\text { Nails }\end{array}$ & Cut Nails & $\begin{array}{c}\text { Forged } \\
\text { Nails }\end{array}$ & $\begin{array}{c}\text { Brick/ } \\
\text { Tile }\end{array}$ & Mortar & Floor Tile & Tar & Other \\
\hline A & $1(0-10)$ & & & & & 2 & 5 & & 1 & \\
\hline A & $2(10-20)$ & & & & 1 & 24 & 8 & & & \\
\hline B & $1(0-10)$ & & & & & 7 & & 1 & 1 & \\
\hline B & $2(10-20)$ & 7 & & & 1 & 5 & 2 & 3 & & 1 \\
\hline C & $1(0-10)$ & & 3 & & & 5 & & & & \\
\hline C & $2(10-20)$ & 7 & & & 3 & 2 & & & & \\
\hline C & $3(20-30)$ & & 2 & 3 & & & & & 2 & \\
\hline D & $1(0-10)$ & 2 & 2 & & & 1 & & & & \\
\hline D & $2(10-20)$ & 1 & & & & 3 & 2 & & & \\
\hline D & $3(20-30)$ & & & & & & 5 & & & \\
\hline
\end{tabular}




\section{Lithics}

\section{Steve A. Tomka}

A total of 23 chipped lithic artifacts was recovered during testing. Twenty-two of the artifacts are unmodified lithic debitage (see Appendix B). The remaining specimen is a gunflint (Figure 14).

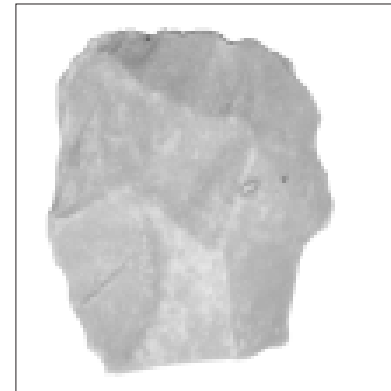

Figure 14. Gunflint.
The single gunflint is made on a short tertiary flake with a longitudinal break along one lateral edge. It has a roughly rectangular shape measuring $25 \mathrm{~mm}$ on each side. Crushing and small step-fractured flake scars indicative of use are present along three of the four edges. The flat break face is the only edge without use-wear. In addition, light polish is present on a number of the flake scar ridges on its dorsal surface. This polish is probably the product of the gunflint's movement against the leather patch which held it in place, and under pressure by the cap screw (see Kenmotsu 1990:Figure 3). Given that the blank is a flake rather than a blade, and given its expedient manufacture, it is probable that the specimen is a native-made gunflint.
The largest number of flakes are from Units B and C (Table 3). The flakes are concentrated mainly in Level $2(n=12)$, although small numbers were also found in Level 1, and Level 3.

The majority of the debitage consisted of tertiary specimens ( $n=17,77$ percent). Interestingly, however, 10 of the 11 (91 percent) platform-bearing flakes have single faceted $(n=7)$ or corticate $(n=3)$ platforms. Eight of the flakes ( 36 percent) are smaller than $20 \mathrm{~mm}$ in maximum dimension and seven of these are platform and/ or core preparation flakes. Seven additional flakes (32 percent) are larger than $30 \mathrm{~mm}$ and at least four of these are core reduction flakes. The remaining six specimens consist of angular debris and unclassifiable specimens.

Although the collection is rather small, it is relatively consistent in technological characteristics. The presence of blade-like flakes representing core reduction, and the absence of debris derived from bifacial reduction, is consistent with technological features observed at a number of other missions in San Antonio (D. Fox 1979; Tomka 1999). Gunflints also are relatively common at most mission sites and reflect the slow technological shift in native armature from the bow and arrow to the EuroAmerican-furnished flintlock muskets.

Table 3. Unmodified debitage by Unit and Level

\begin{tabular}{|c|c|c|c|c|}
\hline Count of Level & \multicolumn{3}{|c|}{ Level } & \\
\hline Unit & $\mathbf{1}$ & $\mathbf{2}$ & $\mathbf{3}$ & Grand Total \\
\hline A & 1 & & & 1 \\
\hline B & 3 & 5 & & 8 \\
\hline C & & 7 & 5 & 12 \\
\hline D & & & 1 & 1 \\
\hline Grand Total & 4 & 12 & 6 & 22 \\
\hline
\end{tabular}




\section{Vertebrate Faunal Remains}

A total of 708 vertebrate faunal remains, weighing 719.41 grams, was recovered during the project. The bone was identified to the most specific taxon possible using the comparative collection at CAR, as well as several reference texts (Boessneck 1970; Cohen and Serjeantson 1996; Gilbert 1990; Hildebrand 1955; Hillson 1986; Olsen 1968). Identifications were conservative, i.e. bone which appeared to be cow-sized was not identified as Bos taurus unless it could be differentiated from Bison and Equus species. All bone was weighed. Evidence of exposure to heat was noted on all bone. Element, portion of element, evidence of immaturity, butcher marks, and pathologies were noted on bone identified to the order taxonomic level. When bone could be identified only to class (e.g., mammal, bird, etc.) an estimate of the size of the animal was made when possible. After analysis, the bone was bagged by unit and level. Bone identified to at least the order taxonomic level was bagged separately and included in the unitlevel bags. Table 4 is a list of the counts and weight of all bone by taxon. A complete provenienced list of faunal data is listed in Appendix C.

Much of the bone is in very fragmented condition, with the average bone weight only 1.1 grams. The bone was not evenly distributed. Almost 75 percent of the bone came from Unit D (Figure 15). Only 14 bones (2 percent) could be identified to the genus taxonomic level.

This collection is too small, and too fragmented to allow useful analysis. However, the large numbers of bone in Unit D do suggest that some areas in the courtyard still contain bone, as well as other trash deposits.

Table 4. Identified Taxa

\begin{tabular}{|c|c|c|c|}
\hline Taxa & Common Name & Count & Weight (g) \\
\hline Mammalia & Mammals & & \\
\hline Artiodactyl & Deer, sheep, goats & 7 & 7.41 \\
\hline Bovinae & Cattle or bison & 2 & 24.34 \\
\hline Capra /Ovis & Goat or sheep & 1 & 7.47 \\
\hline Equus sp. & Horse family & 1 & 5.24 \\
\hline Ovis aries & Domestic sheep & 1 & 10.76 \\
\hline Pecari tajacu & Javelina, collared peccary & 1 & 0.45 \\
\hline Rodentia & Rodents & 1 & 0.08 \\
\hline Sus scrofa & Domestic pig & 2 & 5.25 \\
\hline Mammal--very large & Cattle, bison, horse-sized & 56 & 260.56 \\
\hline Mammal & Size indeterminate & 622 & 387.48 \\
\hline & Total Mammals & 694 & 709.04 \\
\hline Aves & Birds & & \\
\hline Gallus domesticus & Chicken & 2 & 1.39 \\
\hline \multirow[t]{2}{*}{ Aves--large } & Chicken-sized & 1 & 0.48 \\
\hline & Total Birds & 3 & 1.87 \\
\hline Osteichthyes & Boney Fishes & & \\
\hline Ictalurus sp. & Catfish & 6 & 7.04 \\
\hline Pylodictus olivaris & Flathead catfish & 1 & 0.15 \\
\hline \multirow[t]{3}{*}{ Osteichthyes } & Unidentified fish & 4 & 1.31 \\
\hline & Total Fishes & 11 & 8.50 \\
\hline & Overall Totals & 708 & 719.41 \\
\hline
\end{tabular}


Figure 15. Distribution of animal bone by test unit.

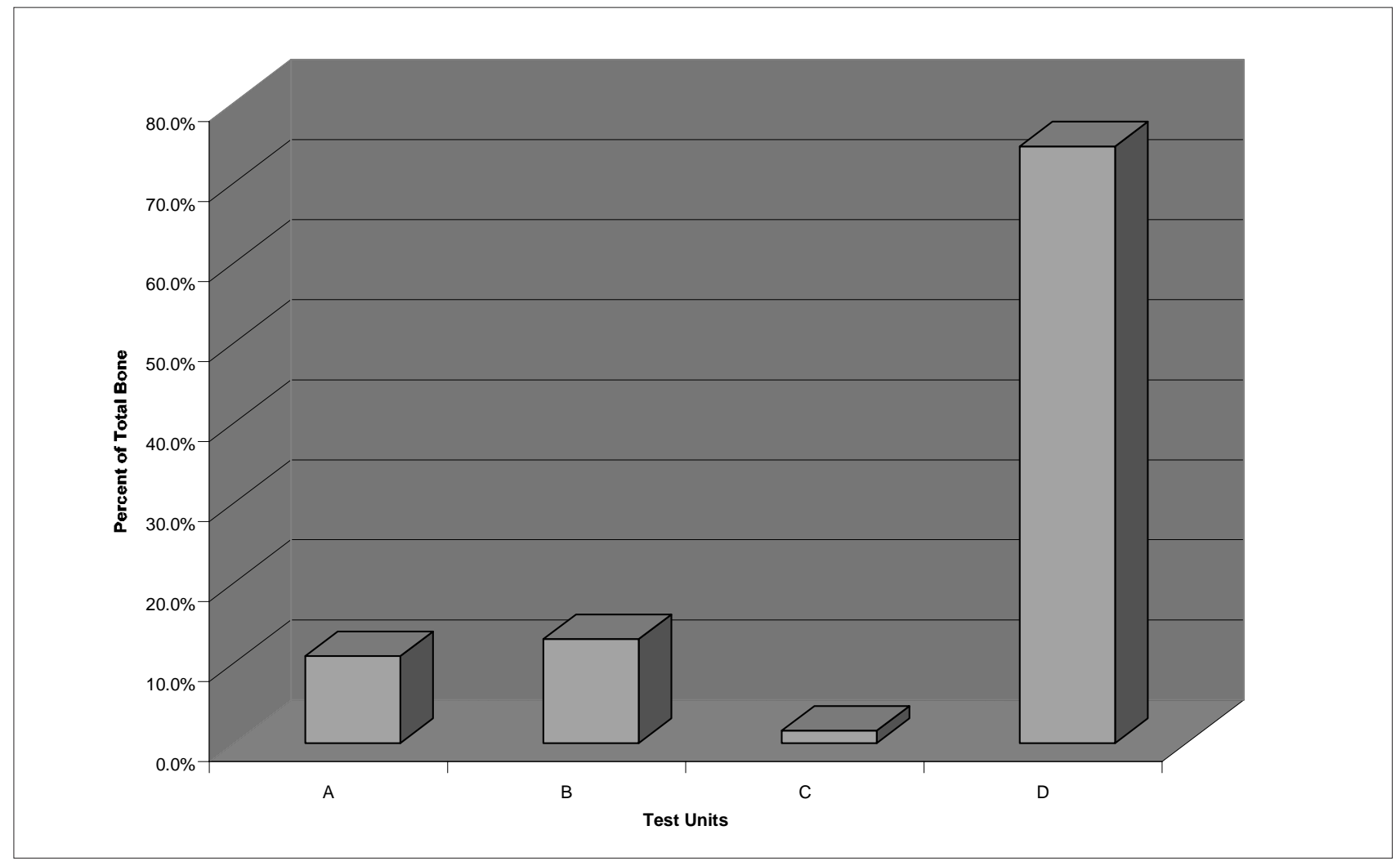

\section{Discussion and Recommendations}

\section{Discussion}

Excavations conducted within the mission courtyard revealed the depth at which the "adobe" flooring appears in the courtyard rooms in four locations (see Figure 3). Elevation measurements were taken to be used in future investigations of the courtyard rooms.

In their discussion of the structural history of Mission Concepción, Ivey and Fox (1999:44-51) indicate that the area now called the courtyard once contained the granary of the mission, along with several other buildings (Figure 16). After secularization, several of these rooms were still in use as the home of Manuel Yturri y Castillo. However, they soon fell into disuse, their stone was taken for other building projects, and by the $1850 \mathrm{~s}$ even the walls of most of these rooms were no longer evident above ground (Ivey and Fox 1999:49).
Figure 16 shows the rooms known to have been constructed and in use in the courtyard area in the latter part of the mission period, as well as walls of previous buildings in the area. What is not clear is whether the area defined by Ivey and Fox (1999:9) as Room 3 was actually used as an enclosed room after the earlier structures were torn down. Also in doubt is the existence of Room 2, as defined by Ivey and Fox (1999:9). This room was conjectured based on the presence of a "floor" of white caliche south of the south wall of Room 1 (Figure 16; see also the unit descriptions in Ivey and Fox 1999:10-13). While this is a reasonable conjecture, it should be noted that excavations at other mission sites in San Antonio have encountered a similar hard-packed caliche layer in areas that are known to have been outside. At Mission San Antonio de Valero (the Alamo), for instance, Meissner found similar hard-packed caliche floors both inside and outside the south transept of the church (Meissner 1996:101; see also Eaton 1980:52). It was apparently a common practice to use packed caliche 


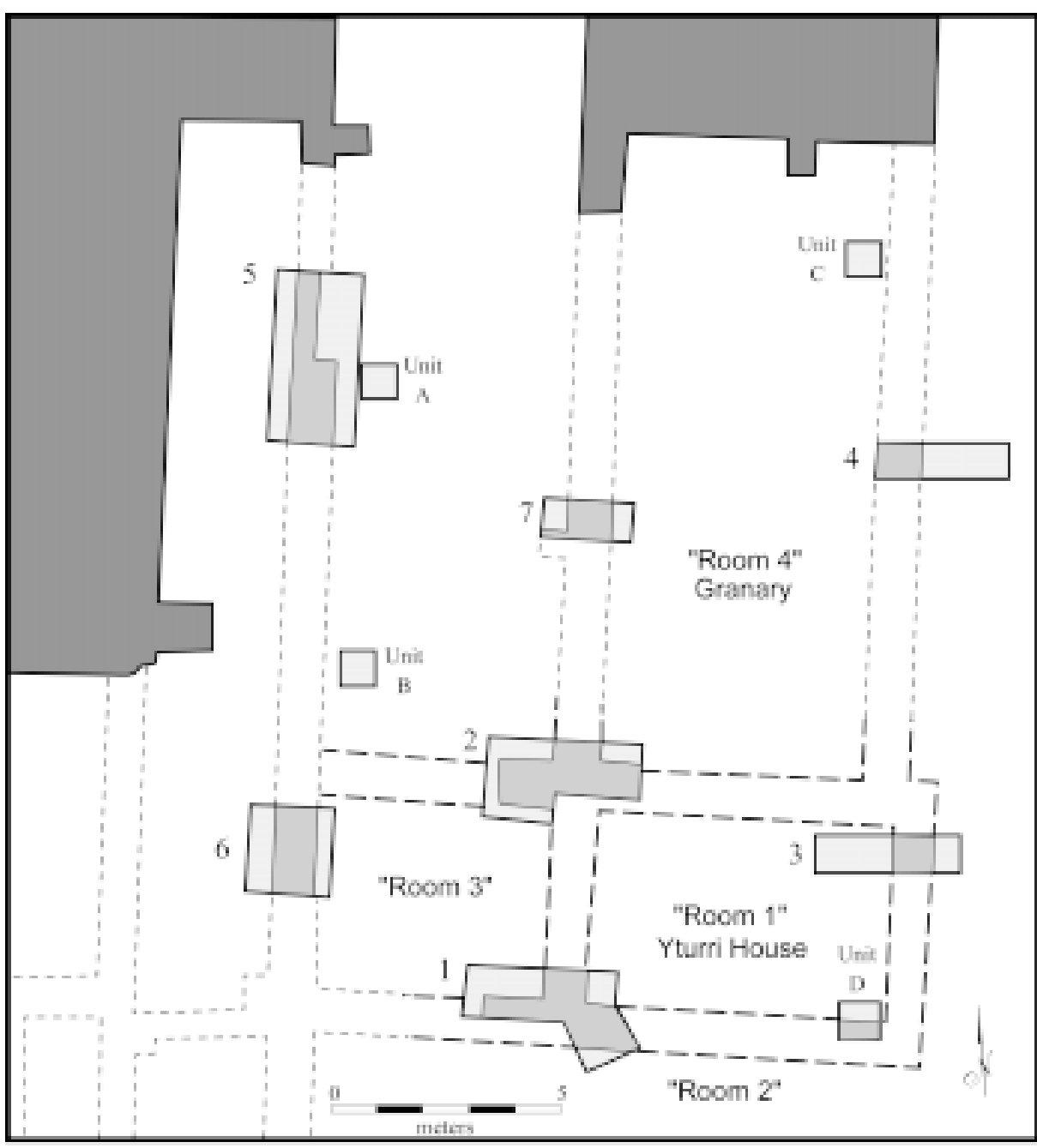

Excavation areas:

$\square$ Existing buildings

1. Block I

2. Block II

3. Block III Fox (1999)

4. Block IV

5. Area A

6. Area B

7. Area C

Krueger and

Unit A

Unit B

Meskill (1992)

Unit C

Current

Unit D

Project

Excavated areas

Walls encountered in archaeological excavations

Walls tentatively identified by WPA excavations (see Scurlock and Fox 1977: Figure 10)

- Walls conjectured by Ivey and Fox (1999)

Figure 16. Known and conjectured rooms in the courtyard area.

(Based on Figure 4 in Ivey and Fox 1999:11, with added information from Kreuger and Meskill 1992). 
as a form of paving, presumably to encourage rain runoff, and lessen muddiness in the immediate vicinity of the mission buildings.

Part of the problem is that it is very difficult, in limited excavation blocks, to tell the difference between walls that have been completely stone-robbed and walls that end, forming buttresses or doorways. Given the limitations of their excavations, for instance, Ivey and Fox conjectured that the walls that ended in the western portions of their Block I and II (see Figure 16) were the edges of doorways. They may, however, have been buttresses, or may not have ended at that location at all, but had simply been more thoroughly stone-robbed. There have been so many construction and demolition episodes, from the mission period through the nineteenth century to the twentieth century, that sorting them out cannot be accomplished by such limited excavations. Krueger and Meskill (1992:17) found that the west side of the courtyard area appeared much more disturbed than more central areas, along the west wall of the granary. This increased level of disturbance no doubt adds to the confusion.
It should be noted, however, that there is evidence that some areas within the courtyard have not been as seriously disturbed as others. Krueger and Meskill (1992:13) found a previously intact trash pit, just outside the west wall of the granary. Ivey and Fox (1999:16) also found a small pit, containing numerous corncob fragments, in the area of Room 3. During this project, Unit D was found to have large numbers of animal bone (Figure 15). In addition, Unit D had by far the largest number of unrefined earthenwares (Figure 17). Although a few unrefined wares were made well into the nineteenth century, most unrefined wares can be considered Colonial in origin, just as most refined wares can be considered post-Colonial in San Antonio (Brown et al. 1994:16). The information in Figures 14 and 15 suggest that the sediments in Unit $D$ were much less disturbed than those in Units A and C, possibly because of the proximity of the wall. The potential for other intact Colonial and early-nineteenth century deposits in the courtyard area provides an important consideration for future planning.

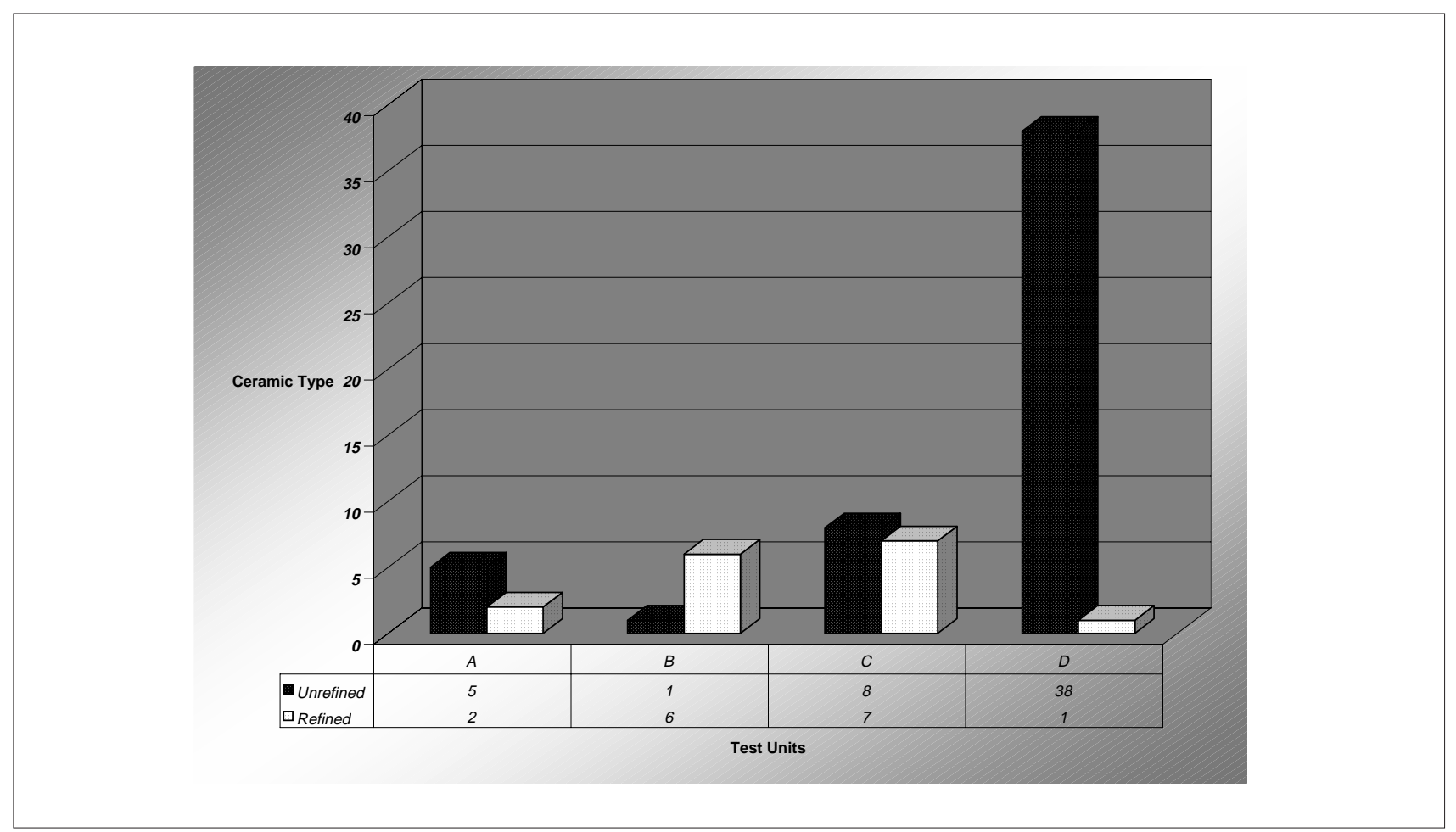

Figure 17. Comparison of refined versus unrefined wares in the four test units. 


\section{Recommendations}

We recommend that archaeologists conduct any excavations in the courtyard area, even if proposed excavations are to be no deeper than the "adobe" floors found in the interior of the rooms. While much of the courtyard area has been disturbed, potentially there is still the possibility that intact Colonial and early-nineteenth century deposits remain, especially in the central and eastern side of the area.

It is likely that excavations to expose the remaining walls of the Colonial period rooms in the courtyard area will find that parts of the walls have been completely destroyed by early stone-robbing, and by modern trenching for various pipelines. However, it may be possible to find the outlines of the trenches in which these walls were originally set -even if the walls themselves are gone (see Hard et al. 1995:28, 31). In addition, evidence of earlier construction episodes, such as the stone and adobe walls uncovered by Ivey and Fox (1999:13), are likely to be encountered. Careful documentation of all features will provide an invaluable addition to our understanding of the series of construction episodes in the courtyard area of Mission Concepción. 


\section{References Cited}

Boessneck, J.

1970 Osteological Differences Between Sheep (Ovis aries Linné) and Goats (Capra hircus Linné). In Science in Archaeology, edited by D. Brothwell and E. Higgs, pp. 331-358. Praeger, New York.

Brown, J. M., A. A. Fox, and B. A. Meissner

1994 Archaeological Testing for the Mission Road Realignment Project, Phase II, at Mission Concepción. Archaeological Survey Report, No. 222. Center for Archaeological Research, The University of Texas at San Antonio.

Cohen, A., and D. Serjeantson

1996 A Manual for the Identification of Bird Bones from Archaeological Sites. Revised edition. Archetype Publications, London.

Cox, I. W., and B. A. Meissner

2000 Historic Background. In Archaeological Investigations at Four San Antonio Missions: Mission Trails Underground Conversion Project, edited by C. L. Tennis, pp. 61-64. Archaeological Survey Report, No. 297. Center for Archaeological Research, The University of Texas at San Antonio.

Dial, S. W.

1992 Ceramics. In Archaeological Investigations in Alamo Plaza, San Antonio, Bexar County Texas: 1988 and 1989, edited by A. A. Fox, pp. 29-46. Archaeological Survey Report, No. 205. Center for Archaeological Research, The University of Texas at San Antonio.

Eaton, J. D.

1980 Excavations at the Alamo Shrine (Mission San Antonio de Valero). Special Report, No. 10. Center for Archaeological Research, The University of Texas at San Antonio.

Fox, A. A.

1988 Archaeological Investigations at Mission Concepción, Fall of 1986. Archaeological Survey Report, No. 172. Center for Archaeological Research, The University of Texas at San Antonio.

1989 Monitoring of Utility Trenches at Mission Concepción, San Antonio, Texas. Archaeological Survey Report, No. 180. Center for Archaeological Research, The University of Texas at San Antonio.

Fox, D. E.

1979 The Lithic Artifacts of Indians at the Spanish Colonial Missions, San Antonio, Texas. Special Report 8. Center for Archaeological Research, the University of Texas at San Antonio.

Gilbert, B. M.

1990 Mammalian Osteology. Missouri Archaeological Society, Columbia.

Habig, M. A.

1968 The Alamo Chain of Missions: A History of San Antonio's Five Old Missions. Franciscan Herald Press, Chicago. 
Hard, R. J., A. A. Fox, I. W. Cox, K. J. Gross, B. A. Meissner, G. I. Méndez, C. L. Tennis, and J. E. Zapata 1995 Excavations at Mission San José y San Miguel de Aguayo, San Antonio, Texas. Archaeological Survey Report, No. 218. Center for Archaeological Research, The University of Texas at San Antonio.

Hildebrand, M.

1955 Skeletal Differences between Deer, Sheep, and Goats. California Fish and Game 41:327-346.

Hillson, S.

1986 Teeth. Cambridge University Press, Cambridge.

Ivey, J. E., and A. A. Fox

1999 Archaeological Investigations at Mission Concepción and Mission Parkway. Archaeological Survey Report, No. 114. Center for Archaeological Research, The University of Texas at San Antonio.

Kenmotsu, N.

1990 Gunflints: A Study. Historical Archaeology 24(2):92-124.

Krueger, M., and F. Meskill

1992 Test Excavations at Mission Concepción Courtyard, San Antonio, Bexar County, Texas. Archaeological Survey Report, No. 214. Center for Archaeological Research, The University of Texas at San Antonio.

Labadie, J. H.

1989 Archaeological and Historical Investigations for the Mission Road Realignment Project, San Antonio, Texas. Archaeological Survey Report, No. 173. Center for Archaeological Research, The University of Texas at San Antonio.

Logan, H. C.

1959 Cartridges: A Pictorial Digest of Small Arms Ammunition. Bonanza Books, New York.

Meissner, B. A.

1996 The Alamo Restoration and Conservation Project: Excavations at the South Transept. Archaeological Survey Report, No. 245. Center for Archaeological Research, The University of Texas at San Antonio.

1997a Making the Man: Clothing Remains from the Alamodome Project. In Archaeology at the Alamodome: Investigations of a San Antonio Neighborhood in Transition, Vol. III, Artifact and Special Studies, edited by A. A. Fox, M. Renner, and R. J. Hard, pp. 119-164. Archaeological Survey Report, No. 238. Center for Archaeological Research, The University of Texas at San Antonio.

1997b Dolls, Toys, Games, and other Diversions. In Archaeology at the Alamodome: Investigations of a San Antonio Neighborhood in Transition, Volume III: Artifact and Special Studies, edited by A. A. Fox, M. Renner, and R. J. Hard, pp. 57-99. Archaeological Survey Report, No. 238, Center for Archaeological Research, The University of Texas at San Antonio.

2000 Mission Concepción. In Archaeological Investigations at Four San Antonio Missions: Mission Trails Underground Conversion Project, edited by C. L. Tennis, pp. 59-99. Archaeological Survey Report, No. 297. Center for Archaeological Research, The University of Texas at San Antonio. 
Olsen, S. J.

1968 Fish, Amphibian, and Reptile Remains from Archaeological Sites Part I: Southeastern and Southwestern United States. Peabody Museum, Cambridge.

Robinson, R. C.

2000 Appendix A3: Concepción. In Archaeological Investigations at Four San Antonio Missions: Mission Trails Underground Conversion Project, edited by C. L. Tennis, pp. 100-104. Archaeological Survey Report, No. 297. Center for Archaeological Research, The University of Texas at San Antonio.

Scurlock, D., and D. E. Fox

1977 An Archeological Investigation of Mission Concepción, San Antonio, Texas. Office of the State Archeologist, Report 28. Austin

Simmons, M., and F. Turley

1980 Southwestern Colonial Ironwork: The Spanish Blacksmithing Tradition from Texas to California. Museum of New Mexico Press, Santa Fe.

Tennis, C. L.

1997 Ceramic patterns and Variations. In Archaeology at the Alamodome: Investigations of a San Antonio Neighborhood in Transition, Vol. III, Artifact and Special Studies, edited by A. A. Fox, M. Renner, and R. J. Hard, pp. 1-37. Archaeological Survey Report, No. 238. Center for Archaeological Research, The University of Texas at San Antonio.

Tomka, S. A.

1999 Historic Period Lithic Technology at Mission San José y San Miguel de Aguayo. Bulletin of the Texas Archeological Society 70:241-263.

Yeoman, R. S.

1967 A Guide Book of United States Coins. Whitman Publishing Company, Racine, Wisconsin. 


\section{Appendix A}

Artifact Data 
Appendix A. Artifacts

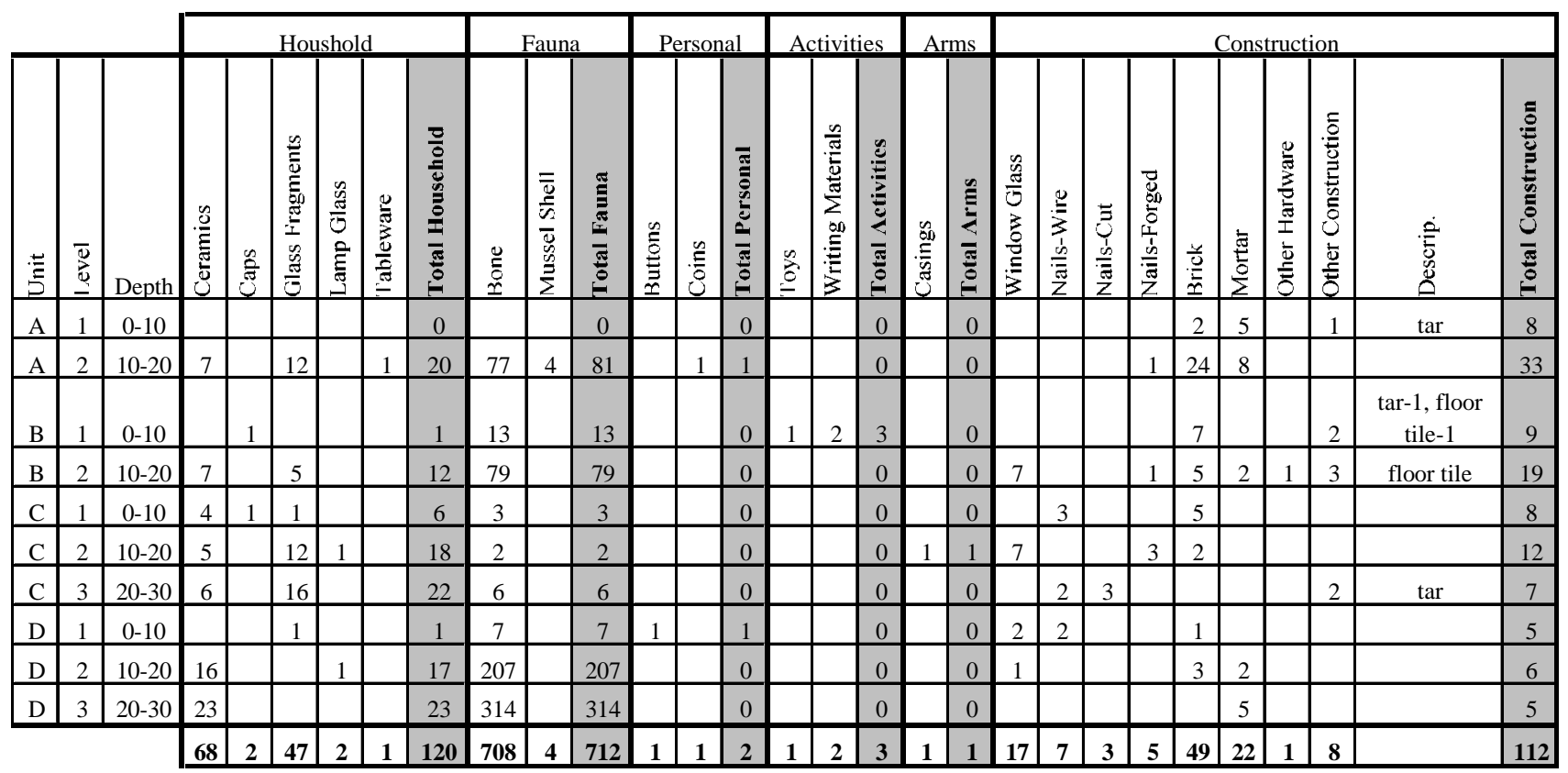

Appendix A. continued...

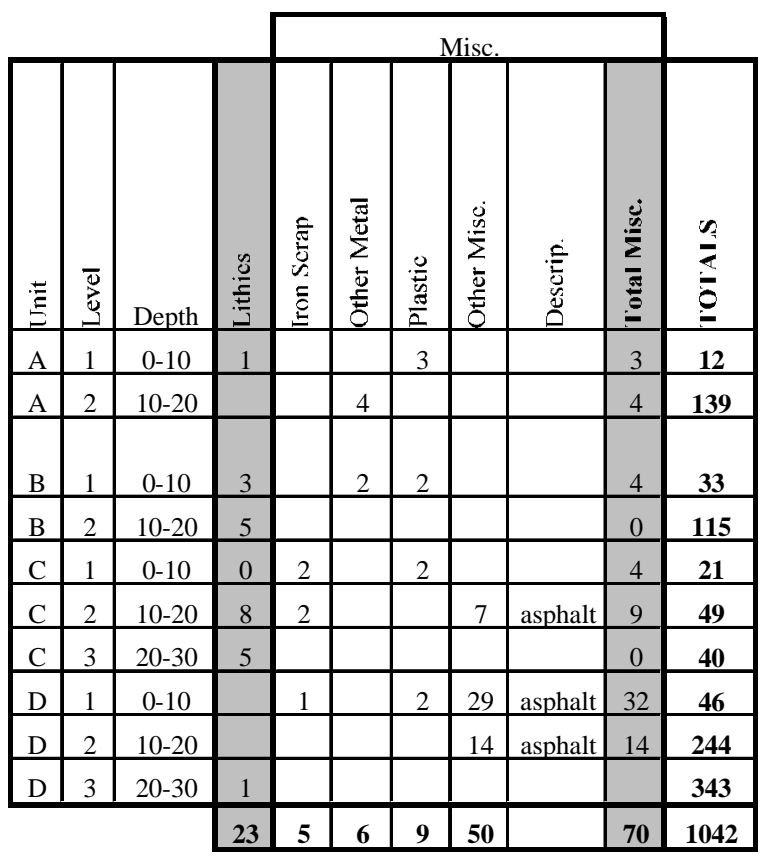




\section{Appendix B}

Lithic Artifacts 
Appendix B. Lithic Artifacts

\begin{tabular}{|c|c|c|c|c|c|c|c|c|}
\hline Lot \# & Unit & Lv. & Material & Completeness & Cortex Cat. & Faceting & Max. Dim. & Flk. Type \\
\hline 1 & A & 1 & f-g chert & proximal & tertiary & single & 4 & core red \\
\hline 2 & B & 1 & $f-g$ chert & complete & tertiary & three & 2 & indet \\
\hline 2 & B & 1 & $f-g$ chert & angular deb & tertiary & na & 2 & angular deb \\
\hline 2 & $\mathrm{~B}$ & 1 & $f-g$ chert & distal & primary & na & 4 & indet \\
\hline 3 & B & 2 & c-g chert & medial & secondary & na & 5 & indet \\
\hline 3 & $\mathrm{~B}$ & 2 & $f-g$ chert & proximal & tertiary & single & 4 & core red \\
\hline 3 & B & 2 & $f-g$ chert & longit & tertiary & corticate & 5 & core red \\
\hline 3 & $\mathrm{~B}$ & 2 & $f-g$ chert & complete & tertiary & single & 2 & plat prep \\
\hline 3 & $\mathrm{~B}$ & 2 & $f-g$ chert & angular deb & secondary & na & 2 & angular deb \\
\hline 7 & $\mathrm{C}$ & 2 & $f-g$ chert & proximal & secondary & single & 5 & core prep \\
\hline 7 & $C$ & 2 & chalcedony & complete & secondary & single & 2 & plat prep \\
\hline 7 & $\mathrm{C}$ & 2 & $f-g$ chert & complete & tertiary & corticate & 2 & plat prep \\
\hline 7 & C & 2 & c-g chert & proximal & tertiary & single & 3 & plat prep \\
\hline 7 & C & 2 & $f-g$ chert & medial & tertiary & na & 2 & indet \\
\hline 7 & $\mathrm{C}$ & 2 & $f-g$ chert & medial & tertiary & na & 2 & plat prep \\
\hline 7 & C & 2 & $f-g$ chert & longit & tertiary & corticate & 3 & plat prep \\
\hline 7 & $\mathrm{C}$ & 2 & chert & complete & tertiary & na & 3 & gunflint \\
\hline 9 & D & 3 & $f-g$ chert & proximal & tertiary & single & 4 & core red \\
\hline 10 & $\mathrm{C}$ & 3 & $f-g$ chert & angular deb & primary & na & 3 & angular deb \\
\hline 10 & $\mathrm{C}$ & 3 & $f-g$ chert & distal & tertiary & na & 2 & core prep \\
\hline 10 & $\mathrm{C}$ & 3 & $f-g$ chert & medial & secondary & na & 2 & indet \\
\hline 10 & C & 3 & $f-g$ chert & proximal & tertiary & single & 2 & biface red \\
\hline 10 & C & 3 & $f-g$ chert & distal & tertiary & na & 2 & re prep \\
\hline
\end{tabular}

$\mathrm{f}-\mathrm{g}=$ fine-grained; $\mathrm{c}-\mathrm{g}=$ coarse-grained

Max. Dim.: $1=0-10 \mathrm{~mm} ; 2=11-20 \mathrm{~mm} ; 3=21-30 \mathrm{~mm} ; 4=31-40 \mathrm{~mm} ; 5=41-50 \mathrm{~mm}$ 


\section{Appendix C}

\section{Faunal Remains}


Appendix C. Faunal Remains

\begin{tabular}{|c|c|c|c|c|c|c|c|c|c|c|c|}
\hline \multicolumn{8}{|c|}{ Appendix C. Faunal Remains } & \multicolumn{2}{|c|}{ Butcher marks } & \multirow[b]{2}{*}{ Gnaw } & \multirow[b]{2}{*}{ Notes } \\
\hline Unit & Level & Taxon & Count & Wgt. (g) & Element & Portion & Juvenile? & Type & Ct. & & \\
\hline A & 2 & Bovinae & 1 & 18.93 & Lumbar vertebra & Fragment & Yes & & & & $\begin{array}{l}\text { Chopped down center } \\
\text { of centrum. }\end{array}$ \\
\hline A & 2 & Bovinae & 1 & 5.41 & Proximal sesmoid & Complete & & & & & \\
\hline A & 2 & Mammal & 69 & 39.87 & & & & & & & \\
\hline A & 2 & Mammal--very large & 4 & 16.4 & & & & & & & \\
\hline A & 2 & Pylodictus olivaris & 1 & 0.15 & Vertebra & Centrum & & & & & \\
\hline $\mathrm{A}$ & 2 & Rodentia & 1 & 0.08 & Humerus & Distal $1 / 2$ & & & & & \\
\hline B & 1 & Gallus domesticus & 1 & 0.48 & 1st phalange (foot) & Complete & & & & & \\
\hline $\mathrm{B}$ & 1 & Mammal & 10 & 7.18 & & & & & & & \\
\hline $\mathrm{B}$ & 1 & Mammal--very large & 2 & 4.44 & & & & & & & \\
\hline B & 2 & Mammal & 76 & 34.47 & & & & & & & \\
\hline B & 2 & Mammal--very large & 3 & 3.89 & & & & & & & \\
\hline $\mathrm{C}$ & 1 & Mammal & 2 & 1.55 & & & & & & & \\
\hline $\mathrm{C}$ & 1 & Mammal--very large & 1 & 9.27 & Long bone & Fragment & & Handsaw & 1 & & \\
\hline $\mathrm{C}$ & 2 & Mammal & 2 & 0.85 & & & & & & & \\
\hline $\mathrm{C}$ & 3 & Mammal & 6 & 2.75 & & & & & & & \\
\hline $\mathrm{D}$ & 1 & Mammal & 6 & 7.09 & & & & & & & \\
\hline $\mathrm{D}$ & 1 & Pecari tajacu & 1 & 0.45 & 1st phalange & Fragment & & & & Canid & \\
\hline $\mathrm{D}$ & 2 & Artiodactyl & 1 & 1.41 & Rib & Fragment & & Chop & 2 & & \\
\hline $\mathrm{D}$ & 2 & Artiodactyl & 1 & 1.76 & Rib & Fragment & & Thin cut & 2 & Canid & \\
\hline $\mathrm{D}$ & 2 & Capra/Ovis & 1 & 7.47 & Molar & & & & & & \\
\hline $\mathrm{D}$ & 2 & Equus sp. & 1 & 5.24 & Rib & Fragment & & & & & \\
\hline $\mathrm{D}$ & 2 & Mammal & 189 & 118.5 & & & & & & & \\
\hline $\mathrm{D}$ & 2 & Mammal--very large & 13 & 50.64 & & & & & & & \\
\hline $\bar{D}$ & 2 & Osteichthyes & 1 & 0.29 & & & & & & & \\
\hline $\mathrm{D}$ & 3 & Artiodactyl & 1 & 2.1 & Rib & Proximal 1/4 & & & & & \\
\hline $\mathrm{D}$ & 3 & Artiodactyl & 1 & 0.87 & Rib & Proximal 1/4 & & & & & \\
\hline $\mathrm{D}$ & 3 & Artiodactyl & 2 & 0.77 & Lumbar vertebra & Epiphysis of centrum & Yes & & & & \\
\hline $\mathrm{D}$ & 3 & Artiodactyl & 1 & 0.5 & Lumbar vertebra & Epiphysis of centrum & Yes & & & & \\
\hline $\mathrm{D}$ & 3 & Aves--large & 1 & 0.48 & & & & & & & \\
\hline $\mathrm{D}$ & 3 & Gallus domesticus & 1 & 0.91 & Ulna & Proximal 1/2 & & & & & \\
\hline $\mathrm{D}$ & 3 & Ictalurus sp. & 4 & 6.72 & Dentary & Almost complete & & & & & Very large \\
\hline $\mathrm{D}$ & 3 & Ictalurus sp. & 1 & 0.16 & Vertebra & Centrum & & & & & \\
\hline $\mathrm{D}$ & 3 & Ictalurus sp. & 1 & 0.16 & Vertebra & Centrum & & & & & \\
\hline $\mathrm{D}$ & 3 & Mammal & 262 & 175.22 & & & & & & & \\
\hline $\mathrm{D}$ & 3 & Mammal--very large & 33 & 175.92 & & & & & & & \\
\hline $\mathrm{D}$ & 3 & Osteichthyes & 3 & 1.02 & & & & & & & \\
\hline $\mathrm{D}$ & 3 & Ovis aries & 1 & 10.76 & Radius & Proximal 1/2 & & & & & \\
\hline $\mathrm{D}$ & 3 & Sus scrofa & 2 & 5.25 & Rib & Proximal 1/4 & & & & & \\
\hline
\end{tabular}

